\title{
Advancement on Lead-Free Organic-Inorganic Halide Perovskite Solar Cells: A Review
}

\author{
Faruk Sani $1, *$ (i) , Suhaidi Shafie ${ }^{2,3}$, Hong Ngee Lim ${ }^{4,5}$ (i) and Abubakar Ohinoyi Musa ${ }^{6}$ \\ 1 Department of Physics, Usmanu Danfodiyo University, P.M.B. 2346, Sokoto, Nigeria \\ 2 Functional Devices Laboratories, Institute of Advanced Technology, Universiti Putra Malaysia, \\ Serdang 43400, Malaysia; suhaidi@upm.edu.my \\ 3 Faculty of Engineering, Universiti Putra Malaysia, Serdang 43400, Malaysia \\ 4 Department of Chemistry, Faculty of Science, Universiti Putra Malaysia, Serdang 43400, Malaysia; \\ hongngee@upm.edu.my \\ 5 Materials Synthesis and Characterization Laboratory, Institute of Advanced Technology, \\ Universiti Putra Malaysia, Serdang 43400, Malaysia \\ 6 Department of Physics, Bayero University, Gwarzo Road, 700241 Kano, Nigeria; aomusa.phy@buk.edu.ng \\ * Correspondence: faruk.sani@udusok.edu.ng; Tel.: +234-803-401-5827
}

Received: 11 April 2018; Accepted: 28 April 2018; Published: 14 June 2018

\begin{abstract}
Remarkable attention has been committed to the recently discovered cost effective and solution processable lead-free organic-inorganic halide perovskite solar cells. Recent studies have reported that, within five years, the reported efficiency has reached 9.0\%, which makes them an extremely promising and fast developing candidate to compete with conventional lead-based perovskite solar cells. The major challenge associated with the conventional perovskite solar cells is the toxic nature of lead $(\mathrm{Pb})$ used in the active layer of perovskite material. If lead continues to be used in fabricating solar cells, negative health impacts will result in the environment due to the toxicity of lead. Alternatively, lead free perovskite solar cells could give a safe way by substituting low-cost, abundant and non toxic material. This review focuses on formability of lead-free organic-inorganic halide perovskite, alternative metal cations candidates to replace lead $(\mathrm{Pb})$, and possible substitutions of organic cations, as well as halide anions in the lead-free organic-inorganic halide perovskite architecture. Furthermore, the review gives highlights on the impact of organic cations, metal cations and inorganic anions on stability and the overall performance of lead free perovskite solar cells.
\end{abstract}

Keywords: halides; inorganic cation; lead free perovskite; solar cells; anions; methyl-ammonium

\section{Introduction}

Organic inorganic halide perovskite solar cells have shown significant improvement of power conversion efficiency (PCE) from the initial efficiency of 3.8\% [1] to about 22\% [2]. The highest theoretical power conversion efficiency achieved by perovskite $\left(\mathrm{CH}_{3} \mathrm{NH}_{3} \mathrm{PbI}_{3}\right)$ is $31.4 \%$ [3]. This remarkable performance is achieved due to unique properties of organic-halide perovskite to exhibit ambipolar transport, high absorption co-efficient, charges carrier mobility, long diffusion length, direct and tunable band gap, simple methods of fabrication [4-6]. Furthermore, the cell is composed of earth-abundant material and attracted tremendous attention in the photovoltaic research field [7]. Perovskite generally refers to any crystalline material with chemical formula $\mathrm{ABX}_{3}$ similar to $\mathrm{CaTiO}_{3}[8]$ as shown in Figure 1. 


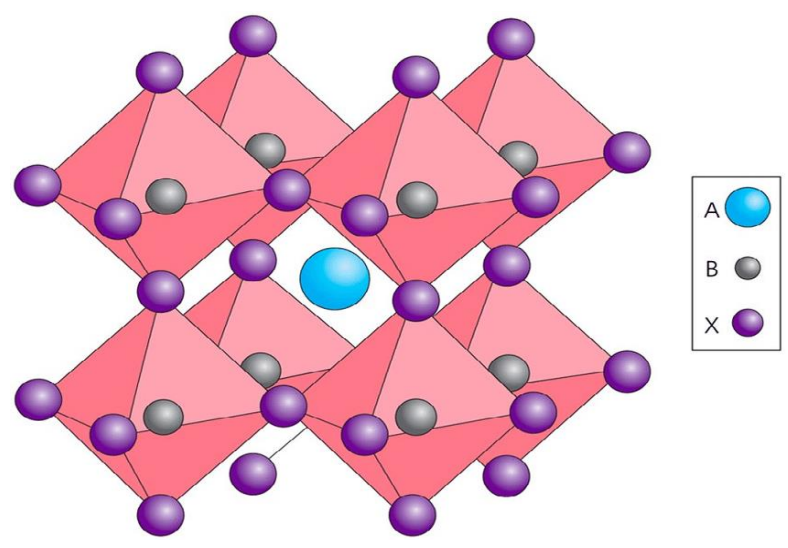

Figure 1. A typical crystal structure of a Perovskite [6].

Most of the materials served as a photo-active layer in perovskite solar cells are comprised of an organo-metal halide. Typically, organic-cation (A) include (methyl-ammonium 'MA', formamidiu 'FA') with a range of divalent metal cations (B) being utilized such as $\mathrm{Cu}^{2+}, \mathrm{Fe}^{2+}, \mathrm{Mn}^{2+}, \mathrm{Pb}^{2+}$, $\mathrm{Sn}^{2+}$, etc. These cations have been mixed with halide anions $(\mathrm{X})$ include $\mathrm{F}^{-}, \mathrm{Cl}^{-}, \mathrm{Br}^{-}$and $\mathrm{I}^{-}$. Combining A-cation, B-cation and X-anion different ratios, various perovskite materials can be obtained [9]. Direct substitution either of the cations or anions may results in distorted perovskite structure or non-perovskite. Goldschmidt Tolerance Factor (GTF) is a dimensionless empirical index which can predict regular crystal structure of a perovskite [10]. GTF is calculated using an expression;

$$
t=\frac{r_{A+r_{X}}}{\sqrt{2}\left(r_{B}+r_{X}\right)}
$$

where $r_{A}$ is an ionic radius of A-cation, $r_{B}$ is an ionic radius of B-cation, and $r_{X}$ is an ionic radius of X-anion.

Generally, tolerance factor, $t$, of $0.9-1.0$ has an ideal cubic structure. Tolerance factor, $t$, less than 0.71 or greater than 1.0 resulted in forming non-perovskite structure [11]. When $t<0.8$, indicates that A-cation is very small and this might distort the formation of perovskite structure, and when $t>1$, the A-cation is very big and this also might result in the formation of non-perovskite. Commonly perovskite structure can be formed in the range, $0.8 \leq t \leq 1.0$. High tolerance factor limit for hybrid iodide perovskite is between 1.06 and 1.07 [12]. In the case of hybrid perovskite due to organic cations and hydrogen bond, GTF cannot absolutely predict their ionic radius. To solve this complexity, Cheetham and co-workers applied rigid sphere model for organic cations and assumed rotational freedom and extended the Goldschmidt Tolerance Factor equation to

$$
t=\frac{r_{A, e f f+r_{X}}}{\sqrt{2}\left(r_{B}+r_{X}\right)}
$$

$r_{A, e f f}$ is given as $r_{\text {mass }}+r_{\text {ion }}$ [13]. The major concern issue for perovskite-based solar cells is the used of heavy metal lead $(\mathrm{Pb})$ in the light absorbing layer. World Health Organization (WHO) has declared lead as an undesirable element causing major societal negative health impacts. Thus there is need for collective effort to protect the health of people in all categories, regardless of age or gender. The Institute for Health Metrics and Evaluation (IHME) estimated that $\mathrm{Pb}$ ingestion is responsible for $9.3 \%$ of world intellectual disorder, $4.0 \%$ of the world problem of heart diseases and $6.6 \%$ of the world problem of stroke [14]. Therefore, photovoltaic community conducted a lot of research aiming to overcome the toxicity challenge in perovskite based solar cells by substituting $\mathrm{Pb}$ with other elements to find an environmentally friendly absorber layer for perovskite solar cells [15]. Recently, many researchers are committed to discover further possible lead-free perovskite absorber material and to modify the device architecture, giving rise to momentous advancement in power conversion efficiency (PCE) of a lead-free organic-inorganic halide 
perovskite solar cell [8]. This review discusses the recent advancement of lead-free organic-inorganic halide perovskite solar cells. It also includes the experimental results, theoretical results of lead-free perovskite solar cells, and focuses on different possible substitutions in the three components of the lead free perovskite absorber layer; organic cations, metal cations and halide anions.

\section{Structure of Lead-Free Organic-Inorganic Hybrid Halide Perovskites}

Lead-free organic-inorganic halide perovskite is class of materials that have the same chemical formula $\mathrm{ABX}_{3}$. In an ideal lead-free organic-inorganic halide perovskite, the $\mathrm{A}^{+}$cation is at the corners of a cube, the $\mathrm{X}^{-}$anion is in the middle of each faces and the small $\mathrm{B}^{+}$(lead free) cation is in the middle of the octahedral sites formed by the anions as shown in Figure 1 [9]. Where A is organic cation (such as ammonium, $\left[\mathrm{NH}_{4}\right]^{+}$, hydroxyl-ammonium, $\left[\mathrm{CH}_{3} \mathrm{OH}\right]^{+}$, methyl-ammonium, $\left[\mathrm{CH}_{3} \mathrm{NH}_{3}\right]^{+}$, formamidinium, $\left[\mathrm{CH}\left(\mathrm{NH}_{2}\right)_{2}\right]^{+}$, ethylammonium, $\left.\left[\mathrm{CH}_{3} \mathrm{CH}_{2}\right) \mathrm{NH}_{3}\right]^{+}$etc.) and $\mathrm{B}$ is inorganic cation, like group 14 element (e.g., $\mathrm{Sn}^{2+}, \mathrm{Ge}^{2+}$ ), alkaline earth metals (such as $\mathrm{Mg}^{2+}, \mathrm{Ca}^{2+}$ etc.), transition divalent metals (such as $\mathrm{Cu}^{2+}, \mathrm{Zn}^{2+}$ etc.), and lanthanide (e.g., $\mathrm{Eu}^{2+}, \mathrm{Yb}^{2+}$ ).Each $\mathrm{B}^{+}$cation mentioned can be served as an alternative to replace divalent lead cation $\left(\mathrm{Pb}^{2+}\right)$ [15]. Perovskite absorber layer consisting Germanium, Silicon, Tin or mixture of either two cations are most suitable in terms of overall photovoltaic performance to replace lead cation [16]. Germanium and Silicon are the best alternatives to lead [17]. These alternative elements $\left(\mathrm{Si}^{2+}, \mathrm{Sn}^{2+}\right.$ and $\left.\mathrm{Ge}^{2+}\right)$ are unstable on exposure to air [18-20]. $\mathrm{X}$ is an anion in the formula and are halogens $\left(\mathrm{F}^{-}, \mathrm{Cl}^{-}, \mathrm{Br}^{-}\right.$and $\left.\mathrm{I}^{-}\right)$or $\left([\mathrm{HCOO}]^{-},\left[\mathrm{CN}^{-},\left[\mathrm{BH}_{4}\right]^{-}\right), \mathrm{SCN}^{-}[13,16]\right.$. The main functions of the inorganic sites are to ensure stability and structural order, while the organic component give the mechanical flexibility and cost effective processing [21] and the $X$ anions maintained the charge neutrality between cations and anions [8]. The stability of organic-inorganic halide perovskite depends on the requirements of Goldschmidt Tolerance Factor. The calculated effective ionic radii of several A-cation, B-cations and X-anion are shown in Table 1.

Table 1. Calculated effective ionic radii of A-organic cations, metal cations and halide anions $[10,13,22,23]$.

\begin{tabular}{|c|c|c|c|c|c|c|c|c|}
\hline A-Cation & $r_{A, e f f} / \mathrm{pm}$ & Ref. & B-Cation & $r_{B, e f f} / \mathrm{pm}$ & Ref. & X-Anion & $r_{X, e f f} / \mathrm{pm}$ & Ref. \\
\hline Ammonium $\left[\mathrm{NH}_{4}\right]^{+}$ & 146 & [13] & $\mathrm{Be}^{2+}$ & 45 & [22] & $\mathrm{I}^{-}$ & 220 & [10] \\
\hline Hydroxylammonium $\left[\mathrm{NH}_{3} \mathrm{OH}\right]^{+}$ & 216 & [13] & $\mathrm{Mg}^{2+}$ & 72 & [22] & $\mathrm{Br}^{-}$ & 196 & [10] \\
\hline Methylammonium $\left[\mathrm{CH}_{3} \mathrm{NH}_{3}\right]^{+}$ & 217 & [13] & $\mathrm{Ca}^{2+}$ & 100 & [22] & $\mathrm{Cl}^{-}$ & 181 & [10] \\
\hline Hydrazinium $\left[\mathrm{NH}_{3} \mathrm{NH}_{2}\right]^{+}$ & 217 & [13] & $\mathrm{Ti}^{2+}$ & 86 & [22] & $\mathrm{F}^{-}$ & 133 & [22] \\
\hline Azetidinium $\left[\left(\mathrm{CH}_{2}\right)_{2} \mathrm{NH}_{2}\right]^{+}$ & 250 & [13] & $\mathrm{V}^{2+}$ & 79 & [22] & & & \\
\hline Formadinium $\left[\mathrm{CH}\left(\mathrm{NH}_{2}\right)_{2}\right]^{+}$ & 253 & [13] & $\mathrm{Cr}^{2+}$ & 80 & [22] & & & \\
\hline Imidazoline $\left[\mathrm{C}_{3} \mathrm{~N}_{2} \mathrm{H}_{5}\right]^{+}$ & 258 & [13] & $\mathrm{Mn}^{2+}$ & 83 & [22] & & & \\
\hline Ethylammonium $\left.\left[\mathrm{CH}_{3} \mathrm{CH}_{2}\right) \mathrm{NH}_{3}\right]^{+}$ & 274 & [13] & $\mathrm{Fe}^{2+}$ & 78 & [22] & & & \\
\hline Guanidinium $\left[\left(\mathrm{NH}_{2}\right)_{3} \mathrm{C}\right]^{+}$ & 278 & [13] & $\mathrm{Ni}^{2+}$ & 69 & [22] & & & \\
\hline Tetramethylammonim $\left[\left(\mathrm{CH}_{3}\right)_{4} \mathrm{~N}\right]^{+}$ & 292 & [13] & $\mathrm{Cu}^{1+}$ & 77 & [22] & & & \\
\hline Thiazolium $\left[\mathrm{C}_{3} \mathrm{H}_{4} \mathrm{~N}_{5}\right]^{+}$ & 320 & [13] & $\mathrm{Cu}^{2+}$ & 73 & [22] & & & \\
\hline 3-pyrollinium $\left[\mathrm{NC}_{4} \mathrm{H}_{8}\right]^{+}$ & 272 & [13] & $\mathrm{Zn}^{2+}$ & 74 & [22] & & & \\
\hline Tropylium $\left[\mathrm{C}_{7} \mathrm{H}_{7}\right]^{+}$ & 333 & [13] & $\mathrm{Ge}^{2+}$ & 73 & [22] & & & \\
\hline Cesium $[\mathrm{Cs}]^{+}$ & 167 & [22] & $\mathrm{Sr}^{2+}$ & 118 & [22] & & & \\
\hline \multirow[t]{13}{*}{ Potassium $[\mathrm{K}]^{+}$} & 138 & [22] & $\mathrm{Ag}^{2+}$ & 94 & [22] & & & \\
\hline & & & $\mathrm{Ag}^{1+}$ & 115 & [22] & & & \\
\hline & & & $\mathrm{Cd}^{2+}$ & 95 & [22] & & & \\
\hline & & & $\mathrm{Ba}^{2+}$ & 135 & [22] & & & \\
\hline & & & $\mathrm{Eu}^{2+}$ & 117 & [22] & & & \\
\hline & & & $\mathrm{Tm}^{2+}$ & 103 & [22] & & & \\
\hline & & & $\mathrm{Yb}^{2+}$ & 102 & [22] & & & \\
\hline & & & $\mathrm{Pt}^{2+}$ & 80 & [22] & & & \\
\hline & & & $\mathrm{Hg}^{2+}$ & 102 & [22] & & & \\
\hline & & & $\mathrm{Np}^{2+}$ & 110 & [22] & & & \\
\hline & & & $\mathrm{Ni}^{2+}$ & 69 & [22] & & & \\
\hline & & & $\mathrm{Sn}^{2+}$ & 115 & [10] & & & \\
\hline & & & $\mathrm{Sb}^{3+}$ & 76 & [23] & & & \\
\hline
\end{tabular}

Typically, there are two major device architectures for organo-metal halide perovskite structure without considering the mesoscopic nano-material; planar heterojuction (n-i-p) and inverted structure 
(p-i-n) [24]. For planar heterojunction, the electron transporting layer (ETL) is spin cast on a glass substrate (e.g., Fluorine-doped tin oxide (FTO)/glass or Indium tin oxide (ITO)/glass followed by perovskite photo-active layer, hole-transporting material (HTL), and finally a metal contact (e.g., silver or gold). In the inverted planar architecture, the hole-transporting material (HTL) is first deposited on a glass substrate then deposition of perovskite layer, electron transporting layer (ETL), and finally a metal contact as shown in the schematic diagram of inverted structure and conventional structure in Figure 2a,b respectively. The most reported inverted planar heterojunction device is PEDOT:PSS [poly (ethylenedioxythiophene): poly (styrene sulfonate)]/perovskite layer/PCBM (phenl-C61-butyric acid methyl ester). In this device, PEDOT:PSS and PCBM function as HTL and ETL respectively. The inverted structure exhibits significant power conversion efficiency (PCE) and virtually free-hysteresis in the voltage-current output, easy fabrication method, and cost effectiveness $[25,26]$. For conventional planar configuration, using metal-oxide (such as $\mathrm{TiO}_{2}, \mathrm{SnO}_{2}$ or $\mathrm{ZnO}$ ) as the electron-transport layer (ETL), the device could show high performance under reverse scan (open-circuit voltage to short circuit current scan). Poor electron injection and extraction exhibited in p-i-n perovskite structure might be due to a barrier at the contact interface between Fermi level of the metal electrode and the lowest un-occupied molecular orbit of the ETM. That is why currently inverted structure is not yet achieved comparable power conversion efficiency to regular planar perovskite architecture [27]. Planar architecture can be further simplified by removing an expensive hole transporting material (HTM) commonly spiro-OMeTAD into a new design called planar HTM-fee architecture [28]. Planar structure with HTM-free is also a promising direction towards reducing the fabrication cost and enhancing the efficiency and stability of perovskite solar cells. Reference [29] designed a planar HTM-free based solar cells and the device exhibited relative stability. This directed towards a potential application of cost effective solar devices.

(a) planar structure

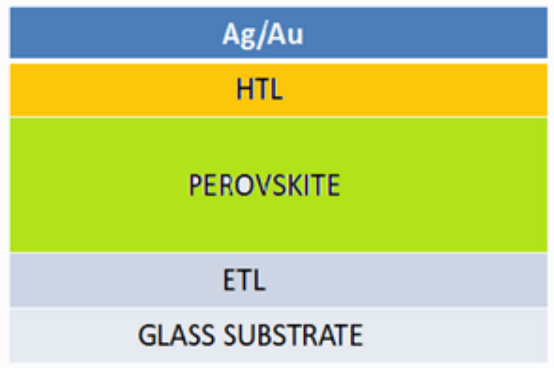

(b) inverted structure

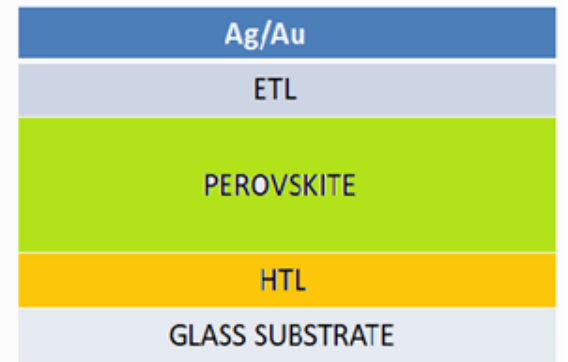

Figure 2. (a) A planar device architecture; (b) An inverted device architecture.

\section{Organic Cation Substitution}

Organic cation in $\mathrm{ABX}_{3}$ plays a significant role in the structural formation of perovskite structures and also has a great effect on the stability and opto-electronic properties of the perovskite material [30]. A cation substitution should strictly base on $\mathrm{BX}_{6}$ octahedral sharing with the respect to a Goldschmidt tolerance factor. A-cation substitution is aimed to obtain more-stable and appropriate dynamic position of the conduction band of the perovskite film [31]. The most extensively studied organic cations in lead free organo metal halide perovskite are methyl-ammonium (MA) and formadinium (FA). Dimentionality and stability of perovskite lattice could be significantly affected by the sizes and functionality of the A-cation [8]. Physical properties such as light absorption and charge transport might also be affected by methyl-ammonium ions $\left(\mathrm{NH}_{3} \mathrm{CH}_{3}{ }^{+}\right)$and formamidinium ions $\left(\mathrm{CH}\left(\mathrm{NH}_{2}\right)_{2}{ }^{+}\right)$[9]. Mixing MA and FA cations show a remarkable performance in the morphology of lead free based perovskite and reduction of charge carrier recombination using (FA) $)_{0.75}(\mathrm{MA})_{0.25} \mathrm{SnI}_{3}$ device structure using $10 \mathrm{~mol} \% \mathrm{SnF}_{2}$ additive and this achieved a power conversion efficiency (PCE) of $8.12 \%$ [32]. Use of volatile cation such as $\mathrm{MA}^{+}$and $\mathrm{FA}^{+}$might be responsible for instability in lead-free 
organic inorganic halide perovskite. Reference [33] employed $\mathrm{Cs}^{+}$in place of methyl-ammonium and formamidinium and resulted in high tolerance to the environment. $\mathrm{Cs}^{+}$in lead-free organic inorganic halide perovskite exhibited stability better than the device with the same structural arrangement using methyl-ammonium lead-iodide perovskite [34]. Lead-free organic-inorganic halide perovskite employed MA or Cs as cation have a smaller size than the same device used FA as an organic cation. The unit cell in $\mathrm{FASnI}_{3}$ has a larger size than the $\mathrm{MASnI}_{3}$ and $\mathrm{CsSnI}_{3}$ and their smaller size resulted in chemical pressure on the inorganic lattice [35]. The differences in size of A-organic cations play the influential role in the stability of perovskite solar cell. In 2016, reference [36] explored a lead-free perovskite solar cell where $\mathrm{Cs}^{+}$is added $\mathrm{SnF}_{2}$ and replaced $\mathrm{MA}^{+}$in cesium tin bromide $\left(\mathrm{CsSnBr}_{3}\right)$ serves as an active layer in the n-i-p structure. The fabricated solar cell achieved power conversion efficiency (PCE) of $2.1 \%$ and this is better than the reported $\mathrm{CsSnBr}_{3}$-based solar cells. This might be due to the incorporation of tin fluoride $\left(\mathrm{SnF}_{2}\right)$ as suggested by the author. Combined small amount of Cs cation in MA based perovskite structure, improves the photovolaic performance but reduces the cell's stability due to the mixture of two different organic cations with different ionic radius [37]. Another combined Cs cation and $\mathrm{Rb}$ cation was reported by [38] in $\mathrm{CsRbSn}_{2} \mathrm{I}_{6}$ lead free absorber layer. The solar cell displays an octahedral rotation pattern and semi-conducting band gap capable of light absorption. The most important remark on $\mathrm{Cs}^{+}$is its owing property of stability improvement in lead free perovskite solar cells. It shows remarkable stability improvement in tin based perovskite when exposed to ambient air [39]. The substitution of $\mathrm{Cs}^{+}$with $\mathrm{MA}^{+}$or $\mathrm{FA}^{+}$resulted in the increase in the volume of the perovskite and hence the band gap increased [40]. Ethylenediammonium (en) as an organic cation improves the air stability and increases the power conversion efficiency (PCE) of lead free organic-inorganic perovskite to $7.14 \%$ in \{en\}FASnI $_{3}$ structure Figure 3 [41]. 2-phenylethyl alcohol (PEAl) is recently introduced as an organic cation in tin-based perovskite solar cells. The presence of PEAl in the device improved the PCE to 6.98\% [42]. This will add another stepping block towards achieving high efficient lead-free perovskite solar cells. Defect tolerance of lead-free perovskites is related to the lattice polarizability and does not require larger organic cation such methyl-ammonium or formamidinium [43]. It was observed that the octahedra deformation increases by the increase in an ionic radius of organic cation [44]. Furthemore, A-cation substitution were found to be responsible for expansion, contraction, or octahedral tilting of the perovskite framework and this could also directly or indirectly affect the bandgap and optical properties of the material [45].

In the struggle for searching suitable organic cations, Goldschmidts tolerance factor, $t$, should be given proper attention for finding essential organic cation such as Hydroxylammonium (216 pm), Hydrazinium (217 pm), 3-pyrollinium (272 pm), Thiazolium (320 pm), Guanidinium (278 pm), and potassium $[13,22]$. The crystal lattice of perovskites expands with the increase in ionic radius of the organic cation (Cesium $<$ methyl-ammonium $<$ formamidinium) [30]. 


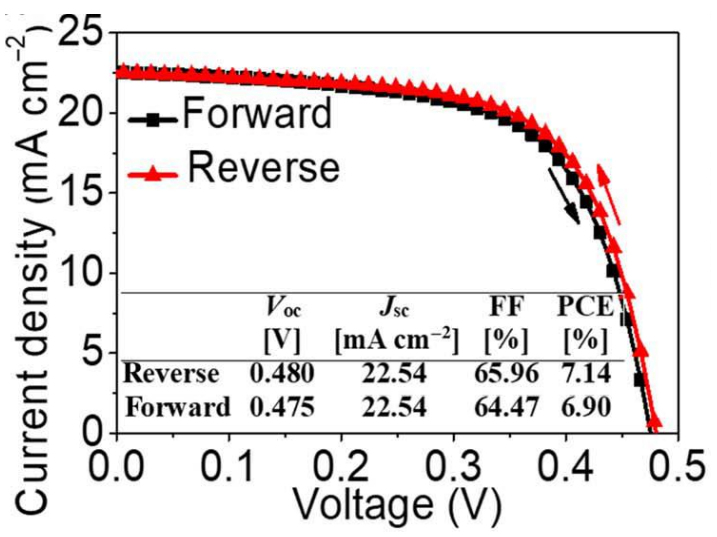

(a)

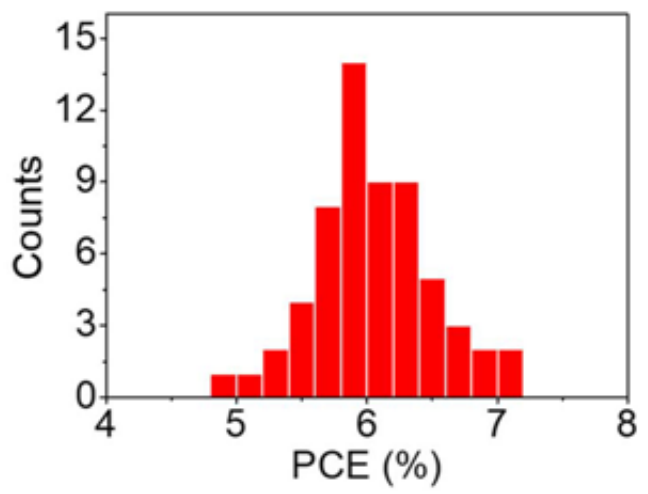

(c)

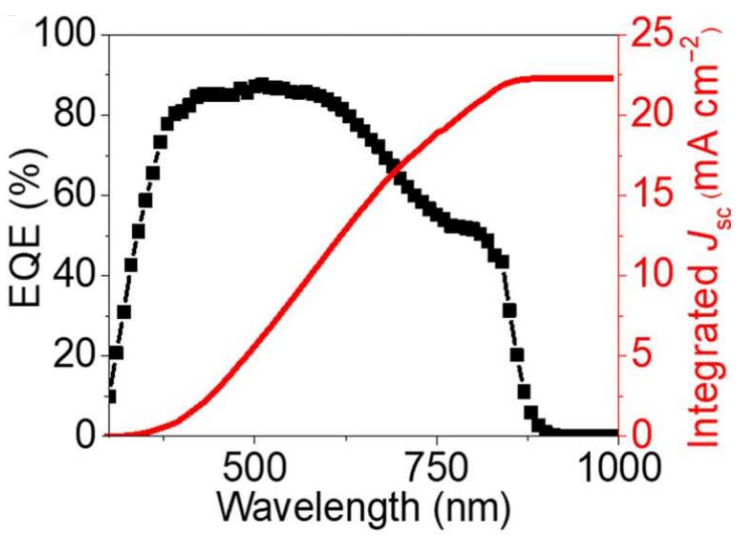

(b)

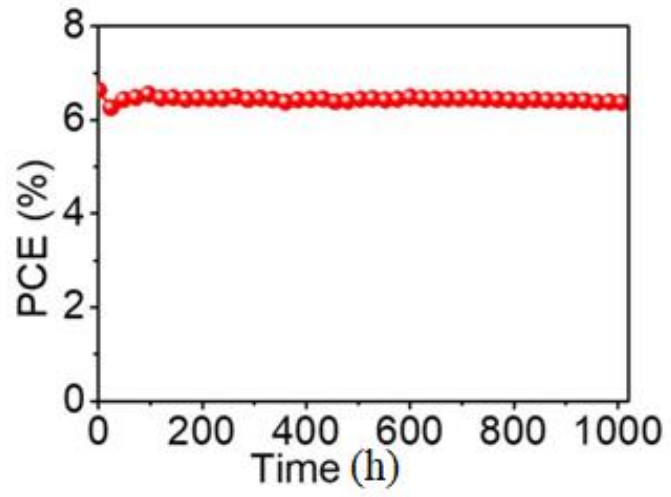

(d)

Figure 3. (a) Current density-Voltage (Jsc-V) of the cell \{en\}FASnI 3 perovskite absorber with $10 \%$ en loading under reverse and forward voltage scan; (b) EQE and integrated Jsc measured from solar cells with $10 \%$ en; (c) Histograms of power conversion efficiencies (PCEs) for $60 \%$ solar cells with $10 \%$; (d) The efficiency of an encapsulated device with $10 \%$ en as a function of the storage time. Reproduced with permission [41]. Copyright American Asociation for the Advancement of Science, 2017.

\section{Inorganic Cation Substitution}

\subsection{Tin Halides}

To achieve Pb-free perovskite solar cells, $\mathrm{Sn}^{2+}$ metal cation was the first divalent metal used as an alternative candidate to replace $\mathrm{Pb}^{2+}$ because of its similar electronic configuration and close effective ionic radius $\left(\mathrm{Sn}^{2+}: 115 \mathrm{pm}\right)$ to lead $\left(\mathrm{Pb}^{2+}: 119 \mathrm{pm}\right)[8,10] . \mathrm{Sn}^{2+}$ has a tendency to oxidize into the $\mathrm{Sn}^{4+}$ state, and this oxidation process might distort the neutrality between cations and anions in the perovskite structure $[15,19,41,46]$. The first reported tin-based perovskite absorber is fabricated by Noel et al. with a structure; FTO/comp-TiO $/$ mesoporousTiO $2 / \mathrm{CH}_{3} \mathrm{NH}_{3} \mathrm{SnI}_{3} / \mathrm{Spiro}-\mathrm{OMeTAD} / \mathrm{Au}$. The planar structure fetched power conversion efficiency (PCE) of $6.4 \%$. To avoid exposure to air, the entire fabrication was carried out inside a glove box. $\mathrm{CH}_{3} \mathrm{NH}_{3} \mathrm{SnI}_{3}$ is a promising candidate to be a light sensitizer with suitable inorganic hole-transport material to achieve cost effective and efficient lead free perovskite solar cell. Reference [47], designed a Sn-based perovskite simulated model and analyzed the photovoltaic performance in planar structure; Glass $/ \mathrm{ZnO} / \mathrm{Al} / \mathrm{TiO}_{2} / \mathrm{CH}_{3} \mathrm{NH}_{3} \mathrm{SnI}_{3} / \mathrm{CuI} / \mathrm{Au}$ using Solar Cell Capacitance Simulator (SCAPS-D1) software. The structure predicts short circuit current of $25.67 \mathrm{~mA} / \mathrm{cm}^{2}$, fill factor of $78.14 \%$, open circuit voltage of $1.0413 \mathrm{~V}$ and power conversion efficiency of about 24.82\% [47]. Reference [36] tackled the issue of the rapid oxidation process of tin when exposed to ambient air by adding $\mathrm{SnF}_{2}$ onto $\mathrm{CsSnBr}_{3}$. It was observed that $\mathrm{SnF}_{2}$ significantly improved the stability of the solar cell and power 
conversion efficiency of $2.1 \%$ was realized. Excess $\mathrm{SnF}_{2}$ functioned as an inhibitor of $\mathrm{Sn}^{4+}$ in $\mathrm{FASnI}_{3}$ based absorber layer and 4.8\% PCE is obtained [48]. For the investigation to enhance the stability of tin-based perovskite, reference [49] reported the synthesized $\mathrm{CsSnBr}_{3}$-based perovskite by selecting precursors and temperature with improved stability. Further optimization using formamidinium (FA) and methyl-ammonium (MA) mixed cations into tin iodide perovskite forming (FA) $)_{0.75}(\mathrm{MA})_{0.25}$ $\mathrm{SnI}_{3}$ yielded high open circuit voltage of $0.61 \mathrm{~V}$, short circuit current of $21.2 \mathrm{~mA} / \mathrm{cm}^{2}$, fill factor of $64.6 \%$ and exhibited power conversion efficiency of $8.12 \%$ [32]. Figure 4 shows the photovoltaic performance of the tin-based perovskite solar cells. Reference [50] controlled crystallization and film formation of $\mathrm{CH}_{3} \mathrm{NH}_{3} \mathrm{SnI}_{3}$ by dissolving equimolar quantities of methyl-ammonium iodide $\left(\mathrm{CH}_{3} \mathrm{NH}_{3} \mathrm{I}\right)$ and tin iodide $\left(\mathrm{SnI}_{2}\right)$ in dimethyl-formamide (DMF) and dimethyl-sulfoxide (DMSO) with gamma-butyrolactone (GBL) in a ratio 3.5:7 respectively. The results illustrate that DMF-based film shows higher surface roughness $\left(R_{\mathrm{rms}}=1.85 \mathrm{~nm}\right)$, good crystallinity and better excited charge carrier extraction in contrast to DMSO-GBL film. This proves that crystallinity and film formation of Sn-based perovskite solar cell can be controlled by choosing a suitable precursor solvent. Further experimental results have recently revealed that mixing small quantity of 2-D PEA $\mathrm{SnI}_{4}$ layered with $3 \mathrm{D} \mathrm{FASnI}_{3}$ perovskite enhance the morphological and orientation of the $3 \mathrm{D} \mathrm{FASnI}$ grain, resulting in a mixture of 2D/3D perovskite. The planar structure; ITO/PEDOT:PSS/FASnI $3 / \mathrm{C} 60+\mathrm{BCP} / \mathrm{Al}$ shows high Voc of $0.525 \mathrm{~V}$, Jsc of $24.1 \mathrm{~mA} / \mathrm{cm}^{2}$, FF of 0.71 , and PCE of $9.0 \%$ [51]. This is the currently highest PCE reported in a lead-free organic-inorganic halide perovskite solar cell. The device performance is shown in Figure 5.
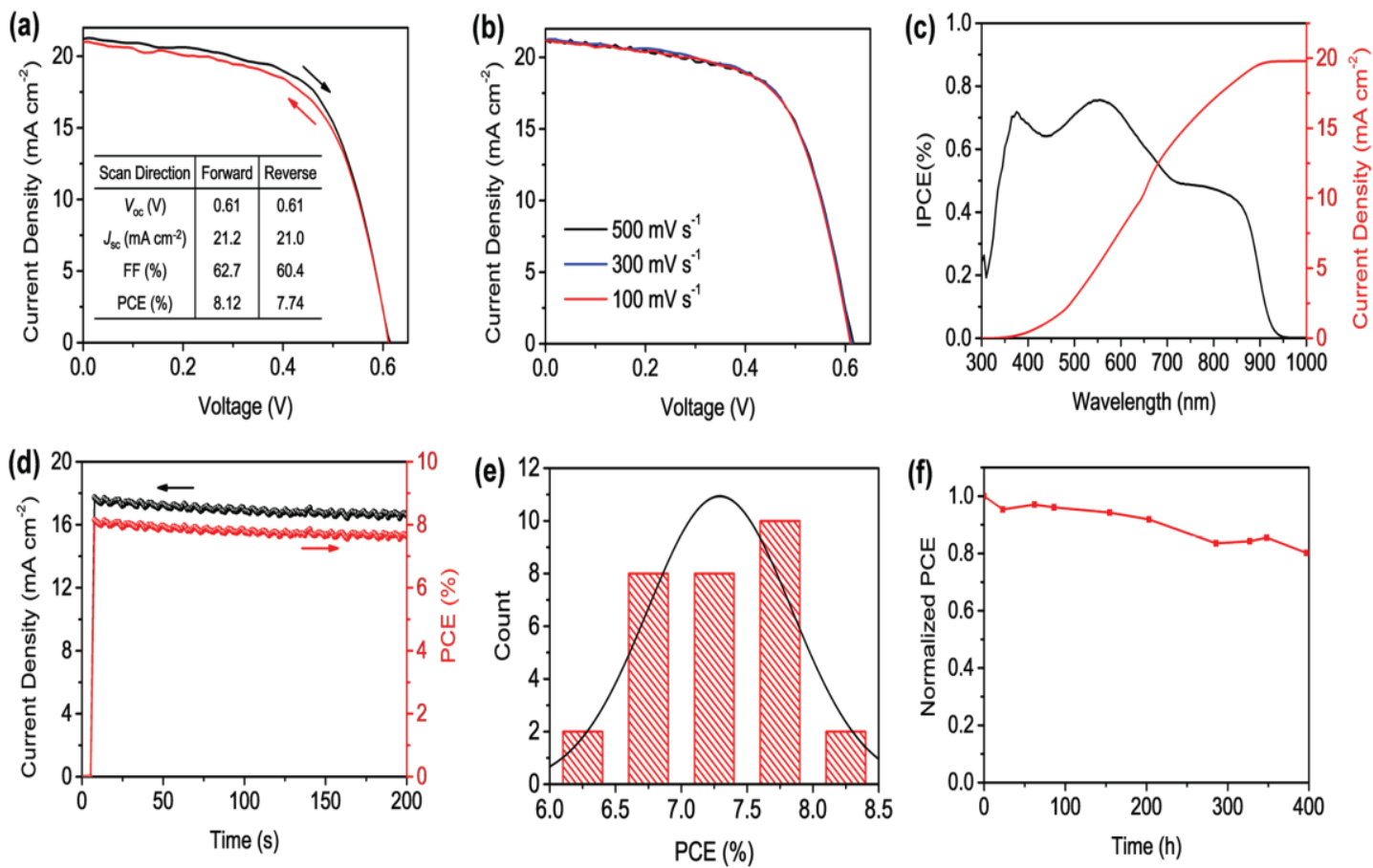

Figure 4. (a) J-V curves of the champion device measured using both forward and reverse scan mode at rate of $300 \mathrm{mV} / \mathrm{s}$ under the simulation of A.M $1.5 \mathrm{G}, 100 \mathrm{~mW} / \mathrm{cm}^{2}$; (b) J-V curves of the champion drvice measured at different scan rates using forward scan mode under the simulation of A.M $1.5 \mathrm{G}, 100 \mathrm{~mW} / \mathrm{cm}^{2}$; (c) Incident photon-to-current efficiency (IPCE) spectrum of the encapsulated (FA) ${ }_{0.75}(\mathrm{MA})_{0.25} \mathrm{SnI}_{3}$ - based device $(\mathbf{d})$ steady state Jsc and PCE of the $(\mathrm{FA})_{0.75}(\mathrm{MA})_{0.25} \mathrm{SnI}_{3}$ measured at a bias of $0.46 \mathrm{~V}$ under AM $1.5 \mathrm{G}, 100 \mathrm{~mW} / \mathrm{cm}^{2}$ irradiation (e) PCE histogram of $30(\mathrm{FA})_{0.75}(\mathrm{MA})_{0.25} \mathrm{SnI}_{3}$-based device from several fabrication batches; (f) Normalized PCE of a $(\mathrm{FA})_{0.75}(\mathrm{MA})_{0.25} \mathrm{SnI}_{3}$-based device stored in glovebox over a period of $400 \mathrm{~h}$. Reproduced with permission [32]. Copyright-WILEY-VCH Verlag, GmbH \& Co. KGaA, Weinheim, Germany, 2017. 

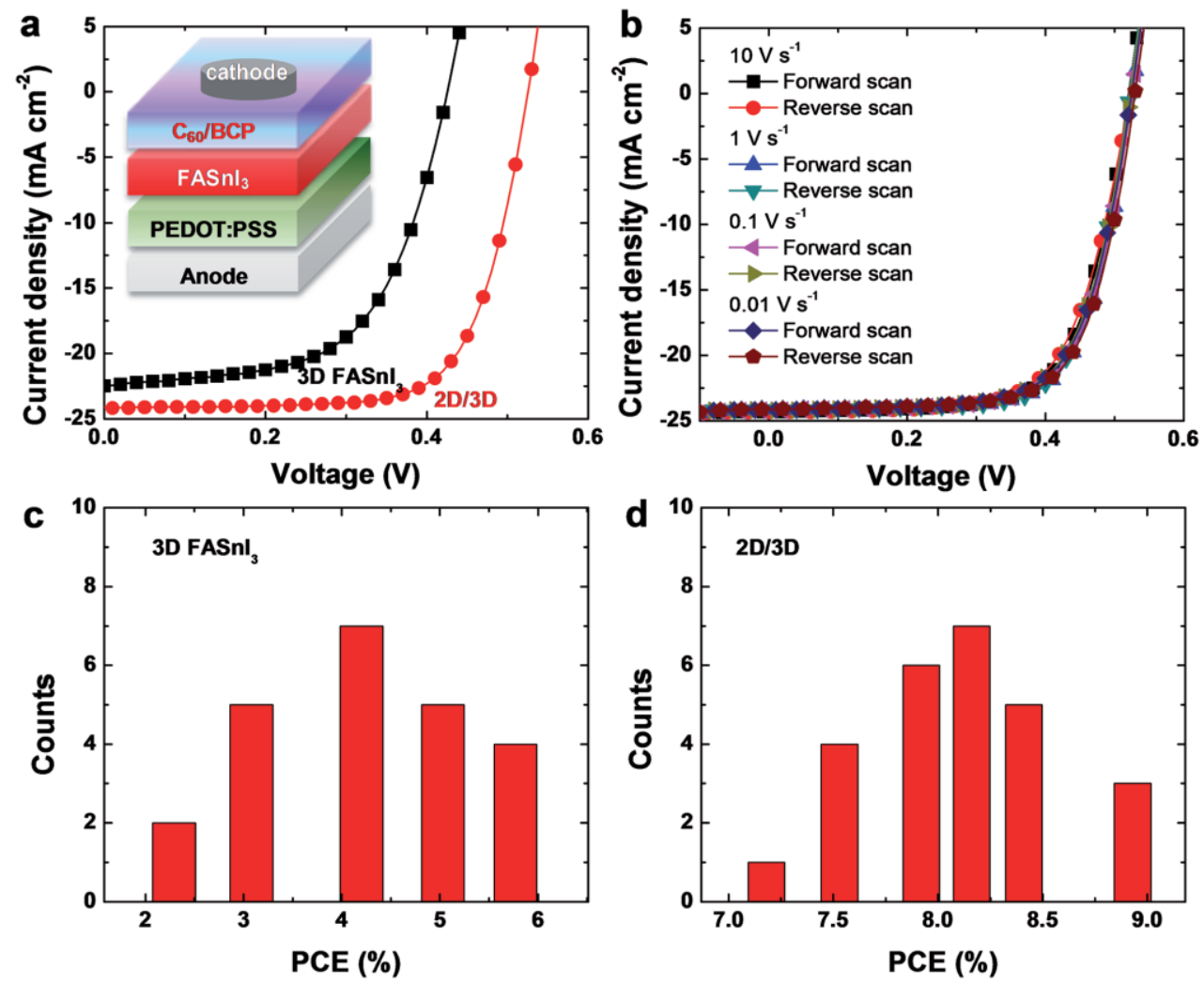

Figure 5. Device structure and characterization. (a) J-V curves under one sun AM 1.5 G condition for the champion devices containing pure 3D and 2D $(0.008 \mathrm{~m}) / 3 \mathrm{D}$ perovskite (the inset shows the device structure); (b) forward and reverse sweeps of the J-V characteristics of the champion 2D/3D perovskite cell measured at different rates; (c) histogram of the reference cell reproducibility, and (d) of the 2D/3D perovskite devices. Reproduced with permission [51]. Copyright-WILEY-VCH Verlag, GmbH \& Co. KGaA, Weinheim, Germany, 2018.

Moreover, a simulated study using SCAP-1D on $\mathrm{CH}_{3} \mathrm{NH}_{3} \mathrm{SnI}_{3}$ based solar cell involving varios hole transport material (HTM) layers (spiro-OMeTAD, $\mathrm{Cu}_{2} \mathrm{O}, \mathrm{CuSCN}$ ). Among the three different structure, $\mathrm{ZnO} / \mathrm{CH}_{3} \mathrm{NH}_{3} \mathrm{SnI}_{3} / \mathrm{Cu}_{2} \mathrm{O} / \mathrm{Au}$ structure predicts the best photovoltaic performance by yielding open circuit voltage $(0.85 \mathrm{~V})$, short circuit current $\left(32.26 \mathrm{~mA} / \mathrm{cm}^{2}\right)$, fill-factor $(74.02 \%)$, and power conversion efficiency (20.23\%) [52]. This structure could be a potential architecture for efficient and inexpensive lead free perovskite solar cells.

\subsection{Germanium Halides}

Another group 14 element called germanium is also potential metal suitable to substitute lead in perovskite solar cells $[8,53]$. Germanium halide perovskites are rarely reported in photovoltaic applications due its oxidation process, relatively small ionic radius and its poor solubility in polar solvents result to too wide band gap $(>1.6 \mathrm{eV})$ and appalling morphology with very low power conversion efficiency (PCE) of only $0.2 \%$ from soluton process [54]. Methyl-ammonium, $\mathrm{CH}_{3} \mathrm{NH}_{3} \mathrm{GeI}_{3}$, formamidinium, $\mathrm{HC}\left[\mathrm{NH}_{2}\right]_{2} \mathrm{GeI}_{3}$, acetamidinium, $\mathrm{CH}_{3} \mathrm{C}\left[\mathrm{NH}_{2}\right]_{2} \mathrm{GeI}_{3}$, guanidinium, $\mathrm{C}\left[\mathrm{NH}_{2}\right] \mathrm{GeI}_{3}$, trimethyl-ammonium, $\left[\mathrm{CH}_{3}\right]_{3} \mathrm{NHGeI}_{3}$ and isopropylammonium $\left[\mathrm{CH}_{3}\right]_{2} \mathrm{C}[\mathrm{H}] \mathrm{NH}_{3} \mathrm{GeI}_{3}$ were synthesized, analysed and concluded that $\mathrm{MAGeI}_{3}$ and $\mathrm{FAGeI}_{3}$ show the best photovoltaic performance [55]. Introducing 10\% bromide ions additive into methyl-ammonium germanium iodide perovskite in p-i-n architecture; ITO/glass/PEDOT:SS/MAGe ${ }_{2.7} \mathrm{Br}_{0.3} / \mathrm{PC}_{70} \mathrm{BM} / \mathrm{Ag}$ improves the power conversion efficiency (PCE) to $0.57 \%$ along with a slight development in the stability of germanium based perovskite solar cell [20]. Mixing cation strategy predicts potentiality of 
$\mathrm{RbSn}_{0.5} \mathrm{Ge}_{0.5} \mathrm{I}_{3}$ as an active layer in lead free perovskite, owing to its direct band gap (0.9-1.6 eV), light absorption which is similar to $\mathrm{MAPbI}_{3}$, high charge carrier mobility and moisture resistance [56].

\subsection{Bismuth Halides Perovskite}

Bismuth is a group 15 metal capable of replacing lead in perovskite solar cells. $\mathrm{Bi}^{3+}$ is an isoelectronic to $\mathrm{Pb}^{2+}$ having the same $6 \mathrm{~s}^{2}$ lone pair, analogous electro-negativity ( $\mathrm{Bi}: 2.02$ and $\mathrm{Pb}: 2.33)$ and possesses effective ionic radius equivalent to divalent lead ions $\left(\mathrm{Bi}^{3+}=103 \mathrm{pm}\right.$ and $\mathrm{Pb} 2=119 \mathrm{pm}$ ) [8]. Organic-inorganic bismuth halides perovskite attracted attention due to stability in ambient atmosphere, less/non-toxic nature and simple method of processing [57]. The early reported bismuth halide perovskites include methyl-ammonium bismuth iodide (MBI) in planar structure; $\mathrm{FTO} /$ comp- $-\mathrm{TiO}_{2} / \mathrm{mesosp}_{-} \mathrm{TiO}_{2} / \mathrm{MBI} / \mathrm{P} 3 \mathrm{HT} / \mathrm{Au}$. This device displayed poor photocurrent performance and thus yielded very low power conversion efficiency of $-0.190 \%$ [57]. This could be due to indirect large band gap. To improve the photocurrent conversion as well as reducing the band gap in bismuth based perovskites, [58] introduced $\mathrm{Cs}^{+}$cation in place of $\mathrm{MA}^{+}$in $\mathrm{CsBi}_{3} \mathrm{I}_{10}$ chemical structure as a light harvester in the perovskite solar devices. The author also compared the device with the previous reported $\mathrm{A}_{3} \mathrm{Bi}_{2} \mathrm{I}_{9}$ (A: methyl-ammonium or cesium) structure by [59]. $\mathrm{CsBi}_{3} \mathrm{I}_{10}$ yields $1.77 \mathrm{eV}$ bandgap which is lower than $2.03 \mathrm{eV}$ band-gap obtained using $\mathrm{Cs}_{3} \mathrm{Bi}_{2} \mathrm{I}_{9}$ and improves the photocurrent up to $700 \mathrm{~nm}$ with low PCE of $0.40 \%$. Calculated bandgaps based on Density Functional Theory (DFT) calculation found direct/indirect band gap of $2.17 \mathrm{eV} / 2.0 \mathrm{eV}$ and $2.17 \mathrm{eV} / 1.97 \mathrm{eV}$ for $\mathrm{Cs}_{3} \mathrm{Bi}_{2} \mathrm{I}_{9}$ and $\mathrm{MA}_{3} \mathrm{Bi}_{2} \mathrm{I}_{9}$ respectively which are tallied with the experimental band-gap values of $2.2 \mathrm{eV}, 2.0 \mathrm{eV}$ and $2.4 \mathrm{eV}, 2.1 \mathrm{eV}$ for $\mathrm{Cs}_{3} \mathrm{Bi}_{2} \mathrm{I}_{9}$ and $\mathrm{MA}_{3} \mathrm{Bi}_{2} \mathrm{I}_{9}$ respectively [60]. In a search for the bismuth halide improvement, optical and structural properties of $\mathrm{CH}_{3} \mathrm{NH}_{3} \mathrm{BiI}_{3}$ were observed. The results show crystalline structure and band gap, $-2 \mathrm{eV}$ and $<0.01 \%$ PCE [61]. Bismuth halide perovskites are stable in ambient air but unfortunately, too large band gap could be responsible for their lower power conversion efficiency. $\mathrm{BiI}_{3}$ is a promising light absorber because of its good optical indirect band gap $(1.57 \mathrm{eV})$ capable of absorbing sunlight in photovoltaic applications [62]. The major challenge in using $\mathrm{BiI}_{3}$ as an active material perovskite solar cell is the mismatched alignment of energy level between $\mathrm{BiI}_{3}$ and $\mathrm{TiO}_{2}$. In this regard, neither single $\mathrm{BiI}_{3}$ nor $\mathrm{A}_{3} \mathrm{Bi}_{2} \mathrm{I}_{9}$ is suitable for efficient absorber in lead-free perovskite solar cells. Thus, reference [63], prepared active layers of $\mathrm{BiI}_{3}$ and $\mathrm{A}_{3} \mathrm{Bi}_{2} \mathrm{I}_{9}$ using chemical solution method under ambient temperature. The composite solar cell significantly increases the open circuit voltage from $0.44 \mathrm{~V}$ to $0.57 \mathrm{~V}$ and power conversion efficiency (PCE) from $0.045 \%$ to $0.076 \%$. One step deposition technique was repeatedly adopted for depositing MBI, in which both $\mathrm{BiI}_{2}$ and methyl-ammonium iodide (MAI) dissolved in a common solvent such as DMF and spin cast on a glass substrate, the fabricated device, may result in poor morpholgy, homogeneity and low film coverage. This might be the factor hindering the good photovoltaic performance of bismuth-based perovskite. Further study towards high efficient bismuth halide absorber in perovskite solar cells revealed that two step method where $\mathrm{BiI}_{3}$ and $\mathrm{CH}_{3} \mathrm{NH}_{3} \mathrm{I}$ were spin coated separately on a mesoporous $\mathrm{TiO}_{2}$ resulted in an increase in PCE to $0.29 \%$ compared with the previous reported PCE [64]. Figure 6 shows the PCE and IPCE of the device using two-step technique by [64]. 


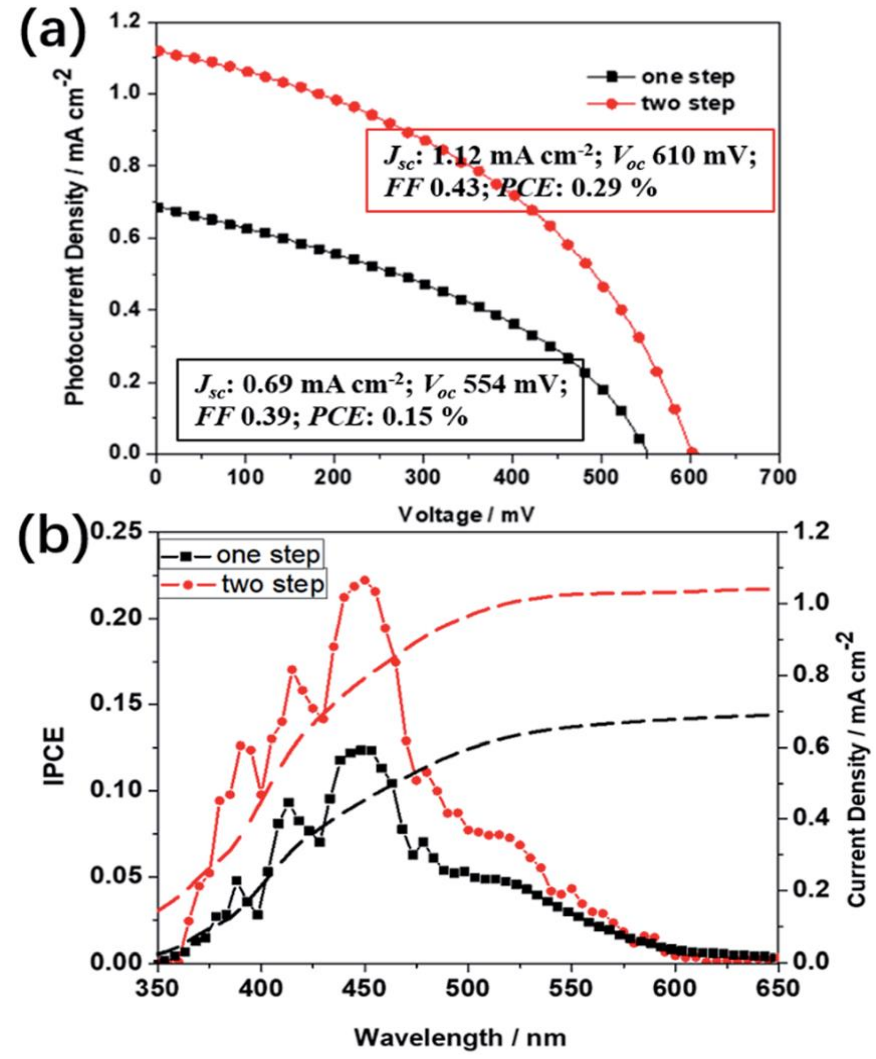

Figure 6. (a) J-V curves for the best performing devices by the one-step and the two-step method, respectively, measured under simulated AM1.5 G irradiation; (b) Corresponding IPCEs. Re-used with permission from [64]. Copyright, Royal Society of Chemistry, 2017.

\subsection{Copper Halide Perouskite}

Copper is one of the earth abundant elements, it is non-toxic and possesses high charge mobility $[65,66]$. The divalent $\mathrm{Cu}^{2+}$ cation is also another alternative element for $\mathrm{Pb}^{2+}$ substitution in perovskite solar cells. $\mathrm{Cu}^{2+}$ is more stable in ambient air than $\mathrm{Sn}^{2+}$ and $\mathrm{Ge}^{2+}[54] . \mathrm{Cu}^{2+}$ has smaller effective ionic radius (73 pm) compared to $\mathrm{Pb}^{2+}(119 \mathrm{pm})$. This hinders the formation 3D perovskite structure. Thus, copper-based halide perovskite form $2 \mathrm{D}$ layered structure type in $\left(\mathrm{R}-\mathrm{NH}_{3}\right)_{2} \mathrm{MX}$ chemical formula. $\mathrm{R}_{4}-\mathrm{NH}_{3}{ }^{+}$are either aliphatic or aromatic ammonium cation, $\mathrm{X}$ are halogens or pseudohalogens, and $\mathrm{M}$ can be monovalent, divalent or trivalent metal ions. The structures are body centered tetragonal and consist of layers of corner sharing $\mathrm{MX}_{6}$ octahedral with $\mathrm{R}^{-\mathrm{NH}_{3}}$ cations occupying holes between the $\mathrm{X}$-anions on either side of the layers [66]. 2D cupric bromide halide perovskite was prepared as a light sensitizer in solar cells. The measured photovoltaic performances of the fabricated device are Jsc, Voc, FF, and PCE with the values; $1.78 \mathrm{~mA} / \mathrm{cm}^{2}, 0.88 \mathrm{~V}, 0.40$, and $0.63 \%$ respectively [66]. Stability of copper halide perovskite could be greatly improved by mixed halides. It has been observed that small quantity of $\mathrm{Cl}^{-}$enhanced crystallization and stability without affecting the photovoltaic performance. Using this development, reference [67] investigated and characterized $\left(\mathrm{CH}_{3} \mathrm{NH}_{3}\right)_{2} \mathrm{CuCl}_{4},\left(\mathrm{CH}_{3} \mathrm{NH}_{3}\right)_{2} \mathrm{CuCl}_{2} \mathrm{Br}_{2},\left(\mathrm{CH}_{3} \mathrm{NH}_{3}\right)_{2} \mathrm{CuClBr}_{3}$, and $\left(\mathrm{CH}_{3} \mathrm{NH}_{3}\right)_{2} \mathrm{CuCl}_{0.5} \mathrm{Br}_{3.5}$. The band gap and the respective absorption coefficient of the absorbers were determined as follows; in $\mathrm{MA}_{2} \mathrm{CuCl}_{4}(2.48 \mathrm{eV}$ and $500 \mathrm{~nm})$, in $\left(\mathrm{CH}_{3} \mathrm{NH}_{3}\right)_{2} \mathrm{CuCl}_{2} \mathrm{Br}_{2}(2.12 \mathrm{eV}$ and $584 \mathrm{~nm})$ for $\left(\mathrm{CH}_{3} \mathrm{NH}_{3}\right)_{2} \mathrm{CuClBr}_{3}(1.90 \mathrm{eV}$ and $625 \mathrm{~nm})$, in $\left(\mathrm{CH}_{3} \mathrm{NH}_{3}\right)_{2} \mathrm{CuCl}_{0.5} \mathrm{Br}_{3.5}(1.80 \mathrm{eV}$ and $689 \mathrm{~nm})$. $\left(\mathrm{CH}_{3} \mathrm{NH}_{3}\right)_{2} \mathrm{CuCl}_{2} \mathrm{Br}_{2}$ and $\left(\mathrm{CH}_{3} \mathrm{NH}_{3}\right)_{2} \mathrm{CuCl}_{0.5} \mathrm{Br}_{3.5}$ have shown better stability. The highest $\mathrm{PCE}$ of $0.017 \%$ is obtained using $\mathrm{MA}_{2} \mathrm{CuCl}_{2} \mathrm{Br}_{2}$. The author suggested that the increased in green photoluminescence intensity is due to $\mathrm{Cu}^{2+}$ reduction to +1 state. This emission is applicable to light emitting devices. Moreover, the effort to conquer the challenges of $\mathrm{Pb}$-based perovskite is extended to the idea of double perovskite with the general formula; $\mathrm{A}_{2}(\mathrm{BC}) \mathrm{X}_{6}$ where $2 \mathrm{~Pb}$ in $\mathrm{APbX}_{3}$ is transmuted into a metal pair $(\mathrm{BC})$ such as $\mathrm{Cu} / \mathrm{Ag}$ or 
$\mathrm{Ga} / \mathrm{In}$. This made $\mathrm{Cu}$-based the leading thin film photovoltaic absorber. The new absorber $\mathrm{Rb}_{2}(\mathrm{CuIn}) \mathrm{Cl}_{6}$ shows a required band gap of $1.36 \mathrm{eV}$ and strong light absorption [68]. The alternative method of double perovskite by incorporating a combination of metals is recently attracting the photovoltaic community towards achieving efficient, non-toxic, cost effective and stable perovskite solar cells. Copper $(\mathrm{Cu})$ and antimony $(\mathrm{Sb})$ are synthesized in $\mathrm{CsCuSb}_{2} \mathrm{Cl}_{12}$ absorber. The $\mathrm{Cu}-\mathrm{Sb}$ based perovskite exhibit a direct band gap of $1.0 \mathrm{eV}$ and good conductivity compared to $\mathrm{MAPbI}_{3}$. Besides, $\mathrm{Cu}-\mathrm{Sb}$ based absorber displays good resistance to temperature and moisture [69].

\subsection{Antimony Halide Perouskite}

Antimony $(\mathrm{Sb})$ is also suitable for lead free absorber layer perovskite. $\mathrm{Sb}^{3+}$ has an effective ionic radius of $76 \mathrm{pm}$ [23] which is smaller compared to $\mathrm{Pb}^{2+}(119 \mathrm{pm})$ and $\mathrm{Sn}^{2+}(110 \mathrm{pm})$. Antimony based perovskites have a typical formula $\mathrm{A}_{3} \mathrm{Sb}_{2} \mathrm{X}_{9}$. Where $\mathrm{A}$, is an organic cation, and $\mathrm{X}(\mathrm{Cl}, \mathrm{Br}, \mathrm{I})$ [8]. Photovoltaic properties of tin iodide have been intensively investigated within the last couple of years, halide complexes of antimony remained unexplored. Bromoantimonates mixed valence complexes containing both $\mathrm{Sb}$ (III) and $\mathrm{Sb}(\mathrm{V})$ were first reported with PCE close to 4\% [70]. Regular structure (n-i-p) shows better photovoltaic performance for antimony halide perovskite as compared with the inverted structure (p-i-n). Reference [71] investigated and compared regular $\mathrm{TiO}_{2} /\left(\mathrm{CH}_{3} \mathrm{NH}_{3}\right)_{3} \mathrm{Sb}_{2} \mathrm{I}_{9} /$ spiro-OMeTAD) and inverted $\left.\mathrm{NiO} /\left(\mathrm{CH}_{3} \mathrm{NH}_{3}\right)_{3} \mathrm{Sb}_{2} \mathrm{I}_{9} / \mathrm{PCMB}\right)$ structures and found that the regular structure performed better with PCE of $0.08 \%$. Chlorine incorporation is a useful tactic to restrain 0-D pattern and stabilize the 2-D phase structure of $\left(\mathrm{CH}_{3} \mathrm{NH}_{3}\right)_{3} \mathrm{Sb}_{2} \mathrm{Cl}_{\mathrm{x}} \mathrm{I}_{9-\mathrm{x}}$. The $\mathrm{Sb}$-based absorber layer recorded $\mathrm{PCE}$ of $2.0 \%$ [72]. Use of sulfur and iodide as anions in $\mathrm{MASbSI}_{2}$ light harvester, allow the incorporation of $3+$ and $4+$ cations to replace 2+ inorganic cations. Power conversion efficiency (PCE) of 3.08\% is realized using $\mathrm{MASbSI}_{2}$ [73]. Predicted results using Density Functional Theory (DFT) calculations shown that the band gap of the mixed-metal perovskite $\left(\mathrm{CH}_{3} \mathrm{NH}_{3}\right)_{2} \mathrm{AgSbI}$ is $2.0 \mathrm{eV}$, which is confirmed by experimental results in which $1.93 \mathrm{eV}$ is obtained for $\mathrm{MA}_{2} \mathrm{AgSbI}_{6}$. Furthermore, the device displays good stability in ambient air [74]. The reported $\mathrm{MA}_{2} \mathrm{AgSbI}_{6}$ perovskites exhibit low PCE. This might be due to its poor surface morphology with many pinholes. Reference [75] optimized the $\mathrm{MA}_{2} \mathrm{Sb}_{2} \mathrm{I}_{9}$ by emp-loying hydroiodic (HI)-chlorobenzene (CB) anti solvent to speed up heterogeneous nucleation of the Sb-based perovskite and also incorporated hydroiodic (HI)-chlorobenzene (CB) inter-layer to minimize the number of vacancies and advance quality of the inverted structure; ITO/PEDOT:PSS/perylene/HI-CB- $\left.\left(\mathrm{CH}_{3} \mathrm{NH}_{3}\right)_{3} \mathrm{Sb}_{2} \mathrm{I}_{9}\right) / \mathrm{PC}_{70} \mathrm{BM} / \mathrm{C}_{60} / \mathrm{BCP} / \mathrm{Al}$. The fabricated device achieved champion power conversion efficiency (PCE) of $2.77 \%$.

\section{Anions Substitutions}

In the organic-inorganic halide perovskite chemical composition $\mathrm{ABX}_{3}, \mathrm{X}$ is an anion in the formula and are usually halogens $\left(\mathrm{F}^{-}, \mathrm{Cl}^{-}, \mathrm{Br}^{-}\right.$and $\left.\left.\mathrm{I}^{-}\right)[76],[\mathrm{HCOO}]^{-},[\mathrm{CN}]^{-},\left[\mathrm{N}_{3}\right]^{-},\left[\mathrm{BH}_{4}\right]^{-}\right)$, $\mathrm{SCN}^{-}$or mixture of them $[6,13,31,76]$. $\mathrm{X}$ anions maintained the charge neutrality between cations and anions [8]. Halogens are highly electronegative and reactive. DFT calculations indicate that the band gap is a function of the geometrical average of electro-negativities, that is, increasing the electro-negativity increases the band gap of the material [40]. One of the unique properties of lead free organic-inorganic halide perovskite is the simple way of altering the structural composition by either changing the A sites or $\mathrm{X}$-site to enhance the photovoltaic performance. Halide ions migration has great impact in determining the overall photovoltaic performance [77]. Modifying the band gaps of organo-metal halide perovskites through halide substitutions may lead to instability of the material for some compositions [78,79]. Halogens (more particularly $\mathrm{Cl}^{-}, \mathrm{Br}^{-}$and $\mathrm{I}^{-}$)) were intensively investigated due to their appropriate effective ionic radii and resulting enhancing the stability as well as the photovoltaic performance. The lead-free tin-iodide based $\mathrm{CH}_{3} \mathrm{NH}_{3} \mathrm{SnI}_{3}$ light absorbers have been widely synthesized and reported by $[18,19,80-82]$ and shown power conversion efficiency (PCE) below $9 \%$ except for [51] recently achieved $9.0 \%$ using $\mathrm{FASnI}_{3}$. This is the recently reported lead-free perovskite with the highest PCE. Generally, the results indicate that iodide contributed significantly 
in the formation of almost regular octahedral but shows poor moisture resistance [45]. In addition, it was observed that in the Sn-based perovskite, the bandgap increases linearly with $\mathrm{I}_{3}, \mathrm{Br}_{3}$, and $\mathrm{Cl}_{3}$ [40]. It was also found that the valence band maximum of $\mathrm{MASnI}_{3}$ is lower than the $\mathrm{MASnCl}_{3}$, and conduction band maximum of $\mathrm{MASnCl}_{3}$ is higher than the $\mathrm{MASnI}_{3}$, resulting to a larger band gap of $\mathrm{MASnCl}_{3}$ [83]. The iodide, $\mathrm{I}^{-}(220 \mathrm{pm})$ is replaced by bromide, $\mathrm{Br}^{-}(196 \mathrm{pm}), \mathrm{Cl}^{-}(181 \mathrm{pm})$, or mixed halides owing similar chemical properties and proved improvement in certain compositions. Nevertheless, formation of cubic perovskite is hindered using $\mathrm{Br}^{-}$(196 pm), $\mathrm{Cl}^{-}$(181 pm) due to their smaller ionic radius compared to $\mathrm{I}^{-}(220 \mathrm{pm})$ [30]. Organic-inorganic perovskite solar cells are potential candidates for achieving power conversion efficiency (PCE) above 20\% [3]. It is believed that organic-inorganic mixed halide perovskite is more efficient than organic-inorganic halide perovskite. This is proved by [84] in tin-based perovskite, $\mathrm{CH}_{3} \mathrm{NH}_{3} \mathrm{SnI}_{3-\mathrm{x}} \mathrm{Br}_{\mathrm{x}}$ in which $5.73 \%$ power conversion efficiency (PCE) is achieved higher than the previous reported PCE using $\mathrm{CH}_{3} \mathrm{NH}_{3} \mathrm{SnI}_{3}$. Chlorine additive significantly helped in achieving layered phase structure, restrained the unwanted OD dimer phase and resulted high quality $\left(\mathrm{CH}_{3} \mathrm{NH}_{3}\right)_{3} \mathrm{Sb}_{2} \mathrm{Cl}_{\mathrm{x}} \mathrm{I}_{9-\mathrm{x}}$ [72]. In addition, excess chlorine in $\mathrm{CH}_{3} \mathrm{NH}_{3} \mathrm{SnCl}_{3}$ found positively influenced the morphological growth of the film, suppressed the oxidation of $\mathrm{Sn}^{2+}$ to 4+ in oxygen, and also maintained same chemical atmosphere as bulk [85]. Pseudohalogen anions with similar chemical properties and ionic radius to halogens can also influence the tolerance factor $\mathrm{t}$ of perovskite [31]. Thiocyanate $\left(\mathrm{SCN}^{-}\right)$anion is a stable pseudohalogen with ionic

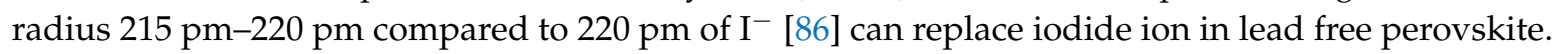
It is suggested that pseudohalogens such as $\mathrm{CN}^{-}, \mathrm{OCN}^{-}$, and $\mathrm{SeCN}^{-}$could be promising substitutes in $\mathrm{X}$ component of future organic-inorganic halide perovskite solar cells [31].

\section{Conclusions}

This review discussed recent advancements on the impact of A-organic cations, B-inorganic cation, and X-anion substitutions on stability, efficiency, and photovoltaic performance of lead-free organic-inorganic halide perovskite. Generally, it concludes that structural modification has great impact on the bandgap and the overall photovoltaic performance of the perovskite solar cells.

Dimensionality and stability of perovskites lattice could be significantly affected by the size of A-cation. It is observed that stability against moisture was remarkably enhanced by substituting FA $^{+}$ by $\mathrm{Cs}^{+}$and mixing MA and FA improved the morphology and reduce the charge carrier recombination of the perovskites. A-cation substitution was found to be responsible for expansion, contraction, or octahedral deformation of the perovskite framework and this could also directly or indirectly influence the bandgap and optical characteristics of the material. Increase in the ionic radius resulted in the increase in bandgap and octahedral deformation in lead-free perovskite solar cells.

Generally, from all the reported lead-free perovskite, Sn-halide perovskite is the champion, efficient and promising candidate to compete with lead based perovskite. Theoretical results predict that $24.82 \%$ PCE could be achieved using tin as a substitute of toxic divalent lead metal. Recently PCE of $9.0 \%$ was reported in tin halide perovskite which is the highest PCE achieved in lead-free based organic-inorganic halide perovskite solar cells. Instability associated with tin halide is the major issue concerning tin-based perovskite. Understanding the process of self doping is required in designing strategies towards achieving long term stability in tin-based perovskite. Recently [87] suggested an immense research on roles on solvent precursors, film thickness, temperature and growth condition, humidity and reductive additives as a future direction to overcome instability in perovskite solar cells. Another strategy to further improve the overall photovoltaic performance is by employing different kinds of photovoltaic polymers and low band gap polymers on top of perovskite [88,89].

Germanium is also found to be a potential divalent metal for replacing lead. $\mathrm{Ge}^{2+}$ is chemically unstable. Ge-based perovskite was reported with wide bandgap $>1.6 \mathrm{eV}$ and very low PCE of $\leq 0.57 \%$. This might be due to its smaller ionic radius $(73 \mathrm{pm})$ and poor solubility in the polar solvent.

Bismuth, $\mathrm{Bi}^{3+}$ is an iso-electronic to $\mathrm{Pb}^{2+}$ having the same $6 \mathrm{~s}^{2}$ lone pair and has effective ionic radius equivalent to $\mathrm{Pb}^{2+}\left(\mathrm{Bi}^{3+}=103 \mathrm{pm}\right.$ and $\left.\mathrm{Pb}^{2+}=119 \mathrm{pm}\right)$. Bismuth attracted attention due to its 
non-toxic nature, ambient stability, and simple solution method processing. Bismuth halide perovskite suffered from too large bandgap resulted in very low PCE of $<0.3 \%$.

Transition metals such as $\mathrm{Cu}$ in particular have appropriate oxidation state to replace lead, although, the corner sharing network of halide octahedral may be compromised due to their smaller ionic radius $\left(\mathrm{Cu}^{+}=77 \mathrm{pm}, \mathrm{Cu}^{2+}=73 \mathrm{pm}\right) . \mathrm{Cu}^{2+}$ is more stable than $\mathrm{Sn}^{2+}$ and $\mathrm{Ge}^{2+}$. The new absorber $\mathrm{Rb}_{2}(\mathrm{CuIn}) \mathrm{Cl}_{6}$ shows a required band gap of $1.36 \mathrm{eV}$, strong light absorption. The highest PCE achieved in $\mathrm{Cu}$ halide perovskite is $0.63 \%$, although, $\mathrm{PCE}$ of $11.2 \%$ is obtained for $\mathrm{Cu}_{2} \mathrm{ZnSn}(\mathrm{Se}, \mathrm{S})$ [90].

Antimony is another alternative to lead due to its good opto-electronic properties and ability to form in different structural dimension ranging from zero dimensional dimer to 3-dimension. PCE of $2.77 \%$ was reported in Sb-halide perovskite with poor surface morphology with many pinholes.

Halide ions play a major role in maintaining the charge neutrality between cations and anions. Halogen with lower electronegativity is essential in achieving appropriate bandgap because bandgap increases linearly with $\mathrm{I}, \mathrm{Br}, \mathrm{Cl}$. Mixing two different halides was found to be more efficient. Pseudohalogens with similar chemical properties with real halogens are potential components in future lead-free organic inorganic perovskite solar cells.

Author Contributions: S.S. revised the paper and funded the work, H.N.L. revised the paper, A.O.M. revised the paper and F.S. wrote the paper.

Funding: This work was carried out in Functional Devices Laboratories, Institute of Advanced Technology, Universiti Putra Malaysia, funded by Universiti Putra Malaysia, Malaysia via PUTRA grant UPM/800-3/3/1/9629800.

Acknowledgments: The author also thanks to the collaboration partners, Usmanu Danfodiyo University, Sokoto, Nigeria and Bayero University, Kano, Nigeria.

Conflicts of Interest: The authors declare no conflict of interest.

\section{References}

1. Kojima, A.; Teshima, K.; Shirai, Y.; Miyasaka, T. Organometal Halide Perovskite as Visible-Light Sensitizer for Photovoltaic Cells. J. Am. Chem. Soc. 2009, 131, 6050-6051. [CrossRef] [PubMed]

2. National Renewable Energy Laboratory. Photovoltaic Research. Official Website. Available online: www.nrel.gov/ncpc/images/efficiency_chart.ipg (accessed on 25 February 2018).

3. Yin, W.J.; Yang, J.H.; Kang, J.; Yan, Y.; Wie, S.H. Halide Perovskite Materials for Solar Cells: A Theoretical Review. J. Mater. Chem. 2015, 3, 8926-8942. [CrossRef]

4. Eperon, G.E.; Burlakov, V.M.; Docampo, P.; Goridy, A.; Snaith, H.J. Morpological Control for High Performance, Solution- Processed Planar Heterojunction Perovskite Solar Cells. Adv. Funct. Mater. 2014, 24, 151-157. [CrossRef]

5. Chen, Q.; Marco, N.D.; Yang, Y.; Song, T.B.; Chen, C.C.; Zhou, H.; Yang, Y. Under the Spotlight: The Organic-Inorganic Hybrid Halide Perovskite for Optoelctronic Applications. Nano Today 2015, 10, 355-396. [CrossRef]

6. Green, M.A.; Baillie, A.H.; Snaith, H.J. The Emergence of Perovskite Solar Cells. Nat. Photonics 2014, 8, 506-514. [CrossRef]

7. Stenberg, J. Perovskite Solar Cells. Master's Thesis, UMEÅ University, Umeå, Sweden, 2017.

8. Hoefler, S.F.; Trimmel, G.; Rath, T. Progress on Lead-Free Metal Halide Perovskite for Photovoltaic Applications: A review. Monatsh. Chem. 2017, 148, 795-826. [CrossRef] [PubMed]

9. Liyan, Y.; Alexander, T.B.; David, G.L.; Tao, W. Recent Progress and Challenges of Organometal Halide Perovskite Solar Cells. Rep. Prog. Phys. 2016, 79, 026501.

10. Nagabhushana, G.P.; Shivaramaih, R.; Navrotsky, A. Direct Calorimetric Verification of Thermodynamic Instability of Lead Halide Hybrid Perovskite. Proc. Natl. Acad. Sci. USA 2016, 113, 7717-7721. [CrossRef] [PubMed]

11. Li, Z.; Yang, M.; Park, J.-S.; Wei, S.-H.; Berry, J.J.; Zhu, K. Stabilizing Perovskite Structures by Tuning Tolerance Factor: Formation of Formamidinium and Cesium Lead Iodide Solid-State Alloys. Chem. Mater. 2016, 28, 284-292. [CrossRef]

12. Travis, W.; Glover, E.N.K.; Bronstein, H.; Scanlon, D.O.; Palgrave, R.G. On the Application of the Tolerance Factor to inorganic and Hybrid Halide Perovskite: A Revised System. Chem. Sci. 2016, 7, 4548-4556. [CrossRef] 
13. Kieslich, G.; Sun, S.; Cheetham, K. Anextended Tolerance Factor Approach for Organic-Inorganic Perovskite. Chem. Sci. 2015, 6, 3430-3433. [CrossRef] [PubMed]

14. WHO. Available online: http:/ / www.who.int/mediacentre/factsheets/fs379/en/ (accessed on 8 April 2018).

15. Giustino, F.; Snaith, H.J. Toward Lead-Free Perovskite Solar Cells. Am. Chem. Soc. 2016, 1, 1233-1240. [CrossRef]

16. Nakajima, T.; Sawada, K. Discovery of Lead-Free Perovskite Solar Cells via High Throughput Simulation on the K Computer. J. Phys. Chem. 2017, 8, 4826-4831.

17. Ali, R.; Hou, G.J.; Zhu, Z.G.; Yan, Q.B.; Zheng, Q.R.; Su, G. Predicted Lead-Free Perovskite for Solar Cells. Am. Chem. Soc. 2018, 30, 718-728. [CrossRef]

18. Saman, G. Organic-Inorganic Hybrid Perovskite as Light Absorbing/Hole Conducting Material in Solar Cells. Master's Thesis, Uppsala University, Uppsala, Sweden, 2013.

19. Noel, N.K.; Stranks, S.D.; Abate, A.; Wahrenfennig, C.; Guarnera, S.; Haghighirad, A.A.; Sadhanala, A.; Eperon, G.E.; Pallack, S.K.; Johnston, M.B.; et al. Lead Free Organic-Inorganic Tin Halide Perovskite for Photovoltaic Application. Energ. Environ. Sci. 2014, 7, 3061-3068. [CrossRef]

20. Kopacic, I.; Friesenbichler, B.; Hoefler, S.F.; Kunert, B.; Plank, H.; Rath, T.; Trimmel, G. Enhanced Performance of Germanium Halide Perovskite Solar Cells through Compositional Engineering. ACS Appl. Energy Mater. 2018, 1, 343-347. [CrossRef]

21. Chilvery, A.; Das, S.; Guggilla, P.; Brantly, C.; Sunda-Meya, A. A Perspective on the Recent Progress in Solution Processed Method for Highly Efficient Perovskite Solar Cells. J. Sci. Technol. Adv. Mater. 2016, 17, 650-658. [CrossRef] [PubMed]

22. Ionic Radius Official Website. Available online: http://www.saylor.org/site/wp-contact/uploads/2011/ 06/Ionic-Radius.pdf/ (accessed on 5 March 2018).

23. Wired Chemist. Officialwebsite. Available online: www.wiredchemist.com/chemistry/data/metallic-radii (accessed on 13 March 2018).

24. Da, P.; Zheng, G. Tailoring Interface of Lead Halide Perovskite Solar Cells. Nano Res. 2017, 10, 1471-1497. [CrossRef]

25. Peng, H.; Sun, W.; Li, Y.; Ye, S.; Rau, H.; Yan, W.; Zhou, H.; Bian, Z.; Huang, C. Solution Processed Inorganic $\mathrm{V}_{2} \mathrm{O}_{\mathrm{x}}$ as Interficial Function Materials for Inverted Planar-heterojunction Perovskite Solar Cells with Enhanced Efficiency. Nano Res. 2016, 9, 2960-2971. [CrossRef]

26. Liu, T.; Chen, K.; Hu, Q. Inverted Perovskite Solar Cells: Progresses and Perspectives. Adv. Energy Mater. 2016, 6. [CrossRef]

27. Bai, Y.; Meng, S.; Yang, S. Interface Engineering for Highly Efficient and Stable Planar P-I-N Perovskite Solar Cells. Adv. Energy Mater. 2018, 8, 1701883. [CrossRef]

28. Atabaev, T.-S. Stable HTM-free organo halide perovskite-based solar cells. Mater. Today Proc. 2017, 4, 4919-4923. [CrossRef]

29. Liu, Y.; Ji, S.; Li, S.; He, W.; Wang, K.; Hu, H.; Ye, C. Study on Hole-Transport-Material-Free planar $\mathrm{TiO}_{2} / \mathrm{CH}_{3} \mathrm{NH}_{3} \mathrm{PbI}_{3}$ Heterojunction Solar Cells: The simplest configuration of a working perovskite solar cell. J. Mater. Chem. A 2015, 3, 14902-14909. [CrossRef]

30. Boix, P.P.; Agarwala, S.; Koh, T.M.; Mathew, N.; Mhaisalkar, S.G. Perovskite Solar Cells: Beyond Methyl-ammonium Lead Iodide. J. Phys. Chem. Lett. 2015, 6, 898-907. [CrossRef] [PubMed]

31. Wang, Z.; Shi, Z.; Li, T.; Chen, Y.; Huang, W. Stability of Perovskite Solar Cells: A Prospective on the Substitution of the A Cation and X Anion. Sol. Cells 2016, 55, 2-25. [CrossRef]

32. Zhao, Z.; Gu, F.; Li, Y.; Sun, W.; Ye, S.; Rao, H.; Liu, Z.; Bian, Z.; Huang, C. Mixed Organic Cation Tin Iodide for Lead Free Perovskite Solar Cells with an Efficiency of 8.12\%. Adv. Sci. 2017, 4, 1700204. [CrossRef] [PubMed]

33. Chen, M.; Ju, M.G.; Carl, A.D.; Zong, Y.; Grimm, R.L.; Gu, J.; Zeng, X.C.; Zhou, Y.; Padture, N. Cesium Titanium (IV) Bromide Thin Film Based Stable Lead-Free Perovskite Solar Cells. Joule 2018, 2, 558-570. [CrossRef]

34. Marshal, K.P.; Walker, M.; Walton, R.I.; Halton, R.A. Enhanced Stability and Efficiency in Hole Transport-layer-Free $\mathrm{CsSnI}_{3}$ Perovskite Photovoltaics. Nat. Energy 2016, 1, 16178. [CrossRef]

35. Fang, H.H.; Adjokatse, S.; Shao, S.; Even, J.; Loi, M.A. Long Lived Hot Carrier Light Emission and Large Blue Shift in Formamidinium Tin Triodide Perovskite. Nat. Commun. 2018, 9, 243. [CrossRef] [PubMed]

36. Gupta, S.; Bendikov, T.; Hodes, G.; Cahen, D. CsSnBr 3 , A Lead-Free Halide Perovskite for Long- Term Solar Cell Application: Insights on SnF2 Addition. ACS Energy Lett. 2016, 1, 1028-1033. [CrossRef] 
37. Laghar, L.; Etgar, L. Effect on Cs on the Stability and Photovoltaic Performance of 2D/3D Perovskite Based Solar Cells. ACS Energy Lett. 2018, 3, 366-372.

38. Gou, J.; Young, J.; Liu, X.; Rondinelli, M. Interplay of Cation Inducing and Ferroelectricity in Perovskite Tin Iodides: Designing a Polar Halide Perovskite for Photovoltaic Applications. Am. Chem. Soc. 2016, 56, $26-32$.

39. Zhang, J.; Li, S.; Yang, P.; Liu, W.; Liao, Y. Enhanced Stability of Lead Perovskite Heterojunction for Photovoltaic Applications. J. Mater. Sci. 2018, 53, 4378-4386. [CrossRef]

40. Castelli, I.E.; Garcia-Lastra, J.M.; Thygesen, K.S.; Jacobsen, K.W. Bandgap Calculations and Trends of Organometal Halide Perovskite. APL Mater. 2014, 2, 081514. [CrossRef]

41. Ke, W.; Stoumpos, C.C.; Zhu, M.; Mao, L.; Spanopoulos, I.; Liu, J.; Kontesevoi, O.Y.; Chen, M.; Samara, D.; Zhang, Y.; et al. Enhanced Photovoltaic Performance and Stability with a New Type Hollow 3D Perovskite \{en\}FASnI 3 . Sci. Adv. 2017, 3, e1701293. [CrossRef] [PubMed]

42. Ran, C.; Xi, J.; Gao, W.; Yuan, F.; Lei, T.; Jiao, B.; Hou, X.; Wu, Z. Bilateral Interface Engineering Towards Efficient 2D-3D Bulk Heterojunction Tin Halide Lead-Free Perovskite Solar Cells. ACS Energy Lett. 2018, 3, 713-721. [CrossRef]

43. Laurita, G.; Fabini, D.H.; Stoumpos, C.C.; Kanatzidis, M.G.; Seshadri, R. Chemical Tuning of Dynamic Cation Centering in the Cubic Phase of Hybrid Tin and Lead Halide Perovskites. Chem. Sci. 2017, 8, 5628-5635. [CrossRef] [PubMed]

44. Amat, A.; Mosconi, E.; Ronca, E.; Quarti, C.; Umari, P.; Nazeeruddin, M.K.; Grätzel, M.; Angelis, F.D. Cation-Induced Band-Gap Tuning in Organohalide Perovskites: Interplay of Spin-Orbit Coupling and Octahedra Tilting. Nano Lett. 2014, 14, 3608-3616. [CrossRef] [PubMed]

45. Borriello, I.; Cantele, G.; Ninno, D. Ab Initio Investigation of Hybrid Organic-Inorganic Perovskite Based on Tin Halides. Phys. Rev. B 2008, 77, 235214. [CrossRef]

46. Qiu, X.; Cao, B.; Yuan, S.; Chen, X.; Qiu, Z.; Jiang, Y.; Ye, Q.; Wang, H.; Zeng, H.; Liu, J.; et al. From Unstable $\mathrm{CsSnI}_{3}$ to Air Stable $\mathrm{Cs}_{2} \mathrm{SnI} 6$ : A Lead Free Perovskite Solar Cells Light Absorber with Bandgap of $1.48 \mathrm{eV}$ and high Absorption Coefficient. Sol. Energy Mater. Sol. Cells 2017, 159, 227-234. [CrossRef]

47. Mandapu, U.; Vedanayakam, S.V.; Thyagarajan, K.; Reddy, M.R.; Babu, B.J. Design and Simulation of High Efficiency Tin Halide Perovskite Solar Cells. Int. J. Renew. Energy Res. 2017, 7, 1603-1612.

48. Lee, S.J.; Shin, S.S.; Kim, Y.C.; Kin, D.; Ahn, T.K.; Noh, J.H.; Seo, J.; Seok, S. Fabrication of Efficient Formamidinium Tin Iodide Perovskite Solar Cells Through $\mathrm{SnF}_{2}-\mathrm{Pyrazine}$ Complex. J. Am. Chem. Soc. 2016, 138, 3974-3977. [CrossRef] [PubMed]

49. Wang, A.; Guo, Y.; Muhammad, F.; Deng, Z. Controlled Synthesis of Lead-Free Cesium Tin Halide Perovskite Cubic Nanocages with High Stability. Chem. Meters 2017, 29, 6493-6501. [CrossRef]

50. Lefanova, A.; Adhikari, N.; Dubey, A.; Khatwada, D.; Qiao, Q. Lead free $\mathrm{CH}_{3} \mathrm{NH}_{3} \mathrm{SnI}_{3}$ perovskite thin-film with p-type semiconducting nature and metal-like conducting. AIP Adv. 2016, 6, 085312. [CrossRef]

51. Shao, S.; Liu, J.; Portale, G.; Fang, H.-H.; Blake, G.R.; Brink, G.H.; Koster, L.A.; Loi, M.A. Highly Reproducible Sn-Based Hybrid Perovskite Solar Cells with 9\% Efficiency. Adv. Energy Mater. 2018, 8, 1702019. [CrossRef]

52. Anwar, F.; Mahbub, R.; Satter, S.S.; Ullah, S.M. Effect of Different HTM Layers and Electrical Parameters on ZnO Nano Rod-Based Lead-Free Perovskite Solar Cell for High-Efficiency Performance. Int. J. Photoenergy 2017, 2017, 9846310. [CrossRef]

53. Krishnamoorthy, T.; Ding, H.; Yen, C.; Leong, W.; Baike, T.; Zhang, H.; Sharburne, M.; Li, S.; Asta, M.; Mathew, N.; et al. Lead Free Germanium Iodide Perovskite Materials for Photovoltaic Applications. J. Mater. Chem. 2015, 3, 23829-238232. [CrossRef]

54. Liang, L.; Gao, P. Lead Free Hybrid Perovskite Absorbers for Viable Application: Can We Eat the Cake and Have it too? Adv. Sci. 2018, 5, 17000331. [CrossRef] [PubMed]

55. Stoumpos, C.C.; Freser, L.; Clerk, D.J.; Kim, Y.S.; Rhim, S.H.; Freeman, A.J.; Ketterson, J.B.; Jang, J.I.; Kanatzidis, M.G. Hybrid Germanium Iodide Perovskite Semiconductors: Active Lone Pairs, Structural Distortions, Direct and Indirect Energy gaps and Strong Nonlinear Optical Properties. J. Am. Chem. Soc. 2015, 137, 680-749. [CrossRef] [PubMed]

56. Ju, M.J.; Dai, J.; Ma, L.; Zeng, X.C. Lead Free Mixed Tin and Germanium Perovskite for Photovoltaic Application. J. Am. Chem. Soc. 2017, 139, 8038-8043. [CrossRef] [PubMed]

57. Lyu, M.; Yun, J.H.; Cai, M.; Jiao, Y.; Bernhardt, P.V.; Zhang, M.; Wang, Q.; Du, A.; Wang, H.; Liu, G.; et al. Organic-Inorganic Bismuth (III)-Based Material: A Lead Free, Air Stable and Solution Proccessibility Light Absorber Beyond Organic Lead Perovskites. Nano Res. 2016, 9, 692-702. [CrossRef] 
58. Johansson, M.B.; Zhu, H.; Johansson, E.M.J. Extended Photo-Conversion Spectrum in Low Toxic Bismuth Halide Perovskite Solar Cells. J. Phys. Chem. Lett. 2016, 7, 3467-3471. [CrossRef] [PubMed]

59. Park, B.W.; Phitippe, B.; Zhang, S.; Rensmo, H.; Boschiloo, G.; Johansson, E.M.J. Bismuth-Based Hybrid Perovskites A3Bi2I9 (A: Methyl-ammonium or cesium) for Solar Cell Application. Adv. Mater. 2015, 27, 6806-6813. [CrossRef] [PubMed]

60. Pazoki, M.; Johonsson, M.B.; Zhu, H.; Broqvist, P.; Edvinsson, T.; Boschloo, G.; Johonsson, E.M. Bismuth Iodide Perovskite Material for Solar Cells Applications: Electronic Structure, Optical Transition, and Directional Charge Transport. J. Phys. Chem. 2016, 120, 29039-29046. [CrossRef]

61. Kwak, C.K.; Barrows, A.T.; Pearson, A.J.; Lidzey, D.G. An X-ray Scattering and Electron Microscopy Study of Methyl-ammonium Bismuth Perovbskite for Solar Cells Applications. J. Mater. Sci. 2017, 32, 1888-1898.

62. Ma, F.; Zhou, M.; Jiao, Y.; Gao, G.; Gu, Y.; Bilic, A.; Chen, Z.; Du, A. Single Layer Bismuth Iodide: Computational Exploration of Structural, Electrical, Mechanical and Optical Properties. Sci. Rep. 2015, 5, 17558. [CrossRef] [PubMed]

63. Lan, C.; Luo, J.; Zhao, S.; Zhang, C.; Liu, W.; Hayase, S.; Ma, T. Effect of Lead- Free $\left(\mathrm{CH}_{3} \mathrm{NH}_{3}\right)_{3} \mathrm{Bi}_{2} \mathrm{I}_{9}$ Perovskite Addition on Spectrum Absorption and Enhanced Photovoltaic Performance of Bismuth Triiodide Solar Cells. J. Alloys Compd. 2017, 701, 834-840. [CrossRef]

64. Wang, H.; Tian, J.; Jiang, K.; Zhang, Y.; Fan, H.; Huang, J.M.; Yang, L.M.; Guan, B.; Song, Y. Fabrication of Methyl-ammonium Bismuth Iodide Through Interdiffusion of Solution-Processed $\mathrm{BiI}_{3} / \mathrm{CH}_{3} \mathrm{NH}_{3} \mathrm{I}$ Stacking Layers. RSC Adv. 2017, 7, 43826-43830. [CrossRef]

65. Haase, D. The GreenWood Encyclopedia of Folktales and Fairly Tales; GreenWood Press: West Port, CT, USA; London, UK, 2008; Volume 1-3.

66. Cui, X.-P.; Jiang, K.-J.; Huang, J.-H.; Zhang, Q.-Q.; Su, M.-J.; Yang, L.-M.; Song, Y.-L.; Zhou, X.-Q. Cupric Bromide hybrid Heterojunction Solar Cells. Synth. Met. 2015, 209, 247-250. [CrossRef]

67. Cortecchia, D.; Dewi, H.A.; Yin, J.; Brono, A.; Chen, S.; Baikie, T.; Boix, P.P.; Gratzel, M.; Mhaisalkar, S.; Soci, C.; et al. Lead-Free $\mathrm{MA}_{2} \mathrm{CuCl}_{\mathrm{x}} \mathrm{Br}_{4-\mathrm{x}}$ Hybrid Perovskites. Am. Chem. Soc. 2016, 55, 1044-1052. [CrossRef] [PubMed]

68. Zhao, X.-G.; Yang, D.; Sun, Y.; Li, T.; Zhang, L.; Yu, L.; Zunger, A. Cu-In Halide Perovskite Solar Absorbers. J. Am. Chem. Soc. 2017, 139, 6718-6725. [CrossRef] [PubMed]

69. Vargas, B.; Ramos, E.; Perez-Gutierrez, E.; Alonso, J.C.; Solis-Ibarra, D. A Direct Bandgap Copper-Antimony Halide Perovskite. J. Am. Chem. Soc. 2017, 139, 9116-9119. [CrossRef] [PubMed]

70. Adonin, S.A.; Frolova, L.A.; Sokolov, M.N.; Shilov, G.B.; Korchagin, D.V.; Fedin, V.P.; Aldoshion, S.M.; Stevenson, K.J.; Troshin, P.A. Antimony (V) Complex Halides: Lead Free Perovskite-Like Marerials for Hybrid Solar Cells. Adv. Energy Mater. 2018, 8, 1701140. [CrossRef]

71. Baranwal, A.K.; Masuntani, H.; Sugita, H.; Kanda, H.; Kanaya, S.; Shibayama, N.; Yamada, K.; Sanehura, Y.; Ikegami, M.; Numata, Y.; et al. Lead Free Perovskite Solar Cells Using Sb, Bi Based $A_{3} B_{2} X_{9}$ and $A_{3} B_{6}$ Crystals with Normal and Inverse Cell Structures. Nano Converg. 2017, 4, 26. [CrossRef] [PubMed]

72. Jiang, F.; Yang, D.; Jiang, Y.; Liu, T.; Zhao, X.; Ming, Y.; Luo, B.; Qin, F.; Fan, J.; Han, H.; et al. Chlorine Incorporation-Induced Formation of the Layered Phase for Antimony-Based Lead Free Perovskite Solar Cells. J. Am. Chem. Soc. 2017, 140, 1019-1027. [CrossRef] [PubMed]

73. Nie, R.; Mehta, A.; Park, B.-W.; Kwon, H.; Im, J.; Soek, S. Mixed Sulfur and Iodide-Based Lead Free Perovskite Solar Cells. J. Am. Chem. Soc. 2018, 140, 872-875. [CrossRef] [PubMed]

74. Li, Y.J.; Wu, T.; Sun, L.; Yang, R.-X.; Jiang, L.; Cheng, P.E.; Hao, Q.-Q.; Wang, T.J.; Lu, R.F.; Deng, W.-Q. Lead Free and Stable Antimony-Silver Halide Double Perovskite $\left(\mathrm{CH}_{3} \mathrm{NH}_{3}\right)_{2} \mathrm{AgSbI}_{6}$. R. Soc. Chem. 2017, 7, 35175-35180. [CrossRef]

75. Karoppuswamy, P.; Boopathy, K.M.; Mohaptra, A.; Chen, H.; Wong, K.-T.; Wang, P.-C.; Chu, C.-C. Role of a Hydrophobic Scaffold in Controlling the Crytallization of Methyl-ammonium Antimony Iodide for Efficient Lead-Free Perovskite Solar Cells. Nano Energy 2018, 45, 330-336. [CrossRef]

76. Filip, M.R.; Giustino, F. Computational Screening of Homovalent Lead Substitution in Organic-Inorganic Halide Perovskites. J. Phys. Chem. 2016, 120, 166-173. [CrossRef]

77. Samu, G.F.; Janaky, C.; Kamat, P.V. A Victim of Halide Ion Segregation. How Light Soaking Affect Solar Cell Performance of Mixed Halide Lead Perovskite. Am. Chem. Soc. 2017, 2, 1860-1861. [CrossRef]

78. Slotcavage, D.J.; Karunadasa, H.I.; McGehee, M.D. Light Induced Phase Segregation in Halide Perovskite Absorbers. Am. Chem. Soc. 2016, 1, 1199-1205. [CrossRef] 
79. McMeekin, D.P.; Sadoughi, G.; Rehman, W.; Eperon, G.E.; Saliba, M.; Horontina, M.I.; Haghighirad, A.; Sakai, N.; Korte, L.; Rech, B.; et al. A mixed Cation Lead Mixed Halide Perovskite Absorber for Tandem Solar Cells. Science 2016, 351, 151-155. [CrossRef] [PubMed]

80. Feng, H.; Costantinos, C.S.; Duyen-Hanh, C.; Robert, P.H.; Mercouri, G.K. Lead Free Solid State Organic-Inorganic Halide Perovskite Solar Cells. J. Nat. Photonics 2015, 8, 489-494.

81. Anastasila, I. Lead Free $\mathrm{CH}_{3} \mathrm{NH}_{3} \mathrm{SnI}_{3}$ Perovskite Thin-Film with P-Type Semiconducting Nature and Metal-Like Conductivity; Department of Electrical Engineering, South Dakota State University: Brookings, SD, USA, 2016.

82. Ozaki, M.; Katsuki, Y.; Liu, J.; Handa, T.; Nishikubo, R.; Yakumaru, S.; Hashikawa, Y.; Murata, Y.; Saito, T.; Shimakawa, Y.; et al. Solvent Cordinated Tin Halide Complexes as Purified Precursors for Tin Based Perovskite. Am. Chem. Soc. 2017, 2, 7016-7021.

83. Shalauddin. First Principle Study of Structural, Electronic and Optical Properties of Lead Free Organic-Inorganic Tin Halide Perovskite for Photovoltaic Applications. Daffodil Int. Univ. J. Sci. Technol. 2017, 12, 1-7.

84. Hao, F.; Stoumpos, C.C.; Cao, D.H.; Chang, R.P.; Kanatzidis, M.G. Lead Free Solid State Organic-Inorganic Halide Perovskite Solar Cells. Nat. Photonics 2014, 8, 489-494. [CrossRef]

85. Moyer, A.; Roy, C. Thermal Engineering of Lead-Free Nanostructured $\mathrm{CH}_{3} \mathrm{NH}_{3} \mathrm{Cl}_{3}$ Perovskite Material for Thin Film Solar Cells. J. Nano Part. Res. 2018, 20, 5.

86. Habisreutinger, S.N.; McMeekin, D.P.; Snaith, H.J.; Nicholas, R.J. Research Update: Strategies for Improving the Stability of Perovskite Solar Cells. APL Mater. 2016, 4, 091503. [CrossRef]

87. Dubey, A.; Adhikari, N.; Mabrouk, S.; Wu, F.; Chen, K.; Yang, S.; Qia, Q. Strategic Review on Processing Routes towards Highly Efficient Perovskite Solar Cells. J. Mater. Chem. A 2018, 6, 2406-2431. [CrossRef]

88. Zhang, S.; Ye, L.; Zhao, W.; Yang, B.; Wang, Q.; Hou, J. Realizing over 10\% efficiency in polymer solar cell by device optimization. Sci. China Chem. 2015, 58, 248-256. [CrossRef]

89. Gao, K.; Zhu, Z.; Xu, B.; Jo, S.; Kan, Y.; Peng, X.; Jen, A.K. Highly Efficient Porphyrin-Based OPV/Perovskite Hybrid Solar Cells with Extended Photoresponse and High Fill Factor. Adv. Mater. 2017, 29, 1703980. [CrossRef] [PubMed]

90. Sun, R.; Zhuang, D.; Zhao, M.; Gong, Q.; Scarpulla, M.; Wei, Y.; Ren, G.; Wu, Y. Beyond 11\% efficiency $\mathrm{Cu}_{2} \mathrm{ZnSn}(\mathrm{Se}, \mathrm{S})$ thin film solar cells by cadmium alloying. Sol. Energy Mater. Sol. Cells 2018, 174, 494-498. [CrossRef] 